\title{
FLEXIBLE JOB SEARCH BEHAVIOUR AMONG UNEMPLOYED JOBSEEKERS: ANTECEDENTS AND OUTCOMES.
}

\author{
Sarah Vansteenkiste ${ }^{1}$, Marijke Verbruggen ${ }^{1}$ and Luc Sels ${ }^{1}$ \\ ${ }^{1}$ Department of Work and Organisation Studies, Faculty of Economics and Business, KU Leuven, Belgium
}

\begin{abstract}
The interest in flexible job search behaviour (FJSB) among unemployed jobseekers, i.e., the extent to which jobseekers also look for jobs that deviate from their studies and earlier work experience, has grown considerably in recent years. Yet, there is large disagreement on both its consequences and drivers. Career scholars as well as policymakers believe that FJSB is important for unemployed and can improve their employment prospects. However, evidence from HR literature raises doubts whether FJSB can enhance reemployment success. Similarly, while the career literature links FJSB to positive attitudes, like career adaptability, the HR literature suggests that people searching flexibly may feel pushed into this behaviour due to more negative reasons, like few labour market perspectives. The aim of this study is examining these opposing expectations. We focus on three FJSB types: flexibility with respect to pay/hierarchical level, skill use and commuting time. Hypotheses are tested using two-wave data with 672 unemployed. Results indicate, among others, that career adaptable people are not inclined to search more flexibly. Additionally, FJSB may in certain cases hamper people's reemployment likelihood. People searching more flexibly also more often became underemployed and as such experienced a more negative job quality.
\end{abstract}

Keywords: flexible job search behavior, unemployment, career adaptability, job search success, underemployment, job quality 


\section{Introduction}

Flexibility among unemployed jobseekers, i.e., the extent to which jobseekers look for jobs that deviate from their studies and earlier work experience (Van den Broeck, 2010; Venn, 2012), is seen as an important searching behaviour on today's labour market. Almost all OECD countries have legislation in which they demand unemployed individuals to search for a new job in a flexible way on a number of aspects (Hasselpflug, 2005; Ministry of Finance, 1998; Vansteenkiste, 2014; Venn, 2012). Most countries expect jobseekers to search flexible regarding the pay level (i.e., an unemployed individual must also search for and accept jobs which offer a lower wage than the previous job or than the usual wage for that occupation), job content (i.e., an unemployed individual must also search for and accept jobs in other occupational areas than his/her previous job or studies), and commuting time (i.e., an unemployed individual must also search for and accept jobs which demand a certain predetermined transportation time). Also career scholars attach great importance to flexibility among the unemployed. As careers have become more volatile, people are more often confronted with job changes and periods of unemployment (Eby, Butts \& Lockwood, 2003; Rousseau, 1997). In this respect, being able to adjust swiftly to different work and career circumstances is deemed indispensable (e.g., Hall, 2004; Koen, Klehe, Van Vianen, Zikic \& Nauta, 2010; Mervish \& Hall, 1994). Searching flexibly is considered to be one of the manners to deal with this increased volatile nature of careers for unemployed persons (Vansteenkiste, Verbruggen \& Sels, 2013).

Despite the importance attached to a flexible job search, different expectations exist with regard to its consequences. Firstly, an important group of policymakers and career scholars presumes that flexibility may help unemployed to regain employment. They believe that flexibility may positively influence people's search effort and as such their chances of being hired (Grubb, 2001; Venn, 2012). Moreover, as flexible jobseekers are less picky, they may accept a job offer 
faster which also may increase their reemployment likelihood. Furthermore, it is anticipated that employers will try to attract flexible individuals, since companies are increasingly working in a turbulent environment and are in need of human flexibility to address this context (e.g. Lawler, 1994; Peiró, García-Montalvo, \& Gracia, 2002; Van den Broeck et al., 2010). Secondly, however, more HR-oriented research on recruitment seems to advocate that flexibility is likely to negatively impact unemployed jobseekers' search success. As organizations base their hiring decisions on the perceived match between the job requirements and applicant's characteristics like education and aspirations (Kristof-Brown, Zimmerman, \& Johnson, 2005; Kulik, Roberson, \& Perry, 2007), a broad job search - thus a high level of flexibility on the part of the individual - may reduce the perceived match as judged by the organization, in that way reducing the likelihood of a job offer. Certain scholars are also concerned that flexibility may increase the likelihood of arriving in an inferior job, which may lead to lower reemployment quality (e.g. Van den Broeck et al., 2010). Despite the many assumptions regarding the impact of flexibility, at present, there is little understanding of the extent to which flexibility actually improves or limits the chances of (re)integration in the labour market and how it influences the quality of reemployment. Hence, before further stimulating flexibility as a policy measure or necessary career skill, we need to know more about its impact on the likelihood and quality of reemployment.

In addition, current research also lacks understanding as to why jobseekers search flexibly. Most career scholars presume that a flexible job search arises from a positive attitude such as being adaptable in one's career. In recent research, four adaptability resources stand out: concern (looking ahead and prepare for what comes next), control (being responsible for shaping oneself and one's environment to meet what comes next), curiosity (thinking about oneself in various situations and roles) and confidence (having the confidence to pursue one's aspirations) (Savickas \& Porfeli, 2012, p. 663). Although each of these dimensions are considered as important to deal with career 
transitions (such as from unemployment to employment), they have not yet been linked to flexible job search behaviour. On the other hand, also negative feelings could push people into a flexible job search. For instance, unemployed individuals experiencing financial or environmental pressure are more likely to develop an employment motive (van Dam \& Menting, 2012) and as such may want to find reemployment as quick as they can by not being very selective in their job search.

As few empirical studies have investigated who searches flexibly and how this behaviour affects reemployment success (Van den Broeck, 2010; Venn, 2012), this study tries to expand the current understanding of flexible job search behaviour by examining its antecedents and outcomes. This study makes several contributions. First, by focussing on flexible job search behaviour, we address the demand for a broader approach towards job search behaviour (e.g., Koen et al., 2010; Saks \& Ashforth, 2002). Indeed, up to now, most studies have concentrated on unemployed individuals' job search intensity (Kanfer, Wanberg \& Kantrowitz, 2001; Saks, 2005) or job search strategy (Crossly \& Highhouse, 2005; Koen et al., 2010), whereas it is widely agreed that much more insight into the unemployment process can be gained from introducing and studying new types of measures of job search behaviour (cf. Koen et al., 2010; Saks \& Ashforth, 2002). Second, by examining the impact of flexible job search behaviour on reemployment success, we address the calls for more studies on the outcomes of this job search behaviour (Van den Broeck et al., 2010). More accurate information on this topic could help to assess the impact and prerequisites of a re-orientation policy more accurately, and to formulate recommendations on measures that could support such a policy. Third, by investigating the antecedents of flexible job search behaviour, we can know better which jobseekers search in a flexible way, which could help interpreting the outcomes of flexible job search behaviour on job search success.

Flexible job search behaviour (FJSB): A multidimensional construct 
In line with the flexibility demands OECD policymakers generally request from unemployed individuals and building on the literature related to the job choice process - i.e., the literature on job design, job fit and willingness to sacrifice - we focus on three dimensions of flexible job search behaviour (FJSB): flexibility with respect to wage/hierarchical level, job content and commuting time.

First, OECD policymakers often expect FJSB from unemployed individuals in terms of pay, i.e., an unemployed individual must also search for and accept jobs that offers a lower wage than his or her previous job or than the usual wage for that occupation (Hasselpflug, 2005; Ministry of Finance, 1998; Venn, 2012). The pay/hierarchical level has also proven to play an important role when deciding on a new job (e.g., Boswell et al., 2003; Osborn, 1990; Konrad, Edgar, Lieb, \& Corrigall, 2000). The amount unemployed jobseekers want to be paid in a future job varies widely, with some jobseekers willing to make concessions upon the wage of their previous job, whereas others not (Feldstein \& Poterba, 1984; Jones, 1989; Hogan, 2004). Hogan (2004) indicated that around $60 \%$ of British jobseekers have wage demands that are less than their previous wage. Along the same lines, a group of Belgian and Dutch scholars, who between the 1970s and 1990s studied the sacrifices unemployed jobseekers are willing to make when offered jobs, also found that the pay/hierarchical level is one of the main aspects unemployed individuals make concessions upon (e.g., Deleeck, Van Hoye, Janssens, \& Peeters, 1988; Kloosterman, 1987; Kroft, Engbersen, Schuyt \& Van Waarden, 1989; Miltenburg, \& Woldringh, 1990; Van Wezel, 1972).

Second, OECD policymakers require, to some extent, that unemployed individuals search flexibly with respect to their job content or skill usage, i.e., an unemployed individual must also look for and accept jobs in other occupational areas than his or her previous job or studies (Hasselpflug, 2005; Ministry of Finance, 1998; Venn, 2012). Literature suggests that this is also 
one of the key factors jobseekers take into account when deciding on a new job (Boswell et al., 2003; Chapman et al., 2005; Taylor \& Bergmann, 1987; Turban, Eyring \& Campion, 1993; Turban et al., 2001). Research suggests that in order to find reemployment, a large proportion of unemployed jobseekers (up to $50 \%$ and more) are willing to accept jobs that require retraining (e.g., Kloosterman, 1987; Kroft et al., 1989; Miltenburg \& Woldringh, 1990; Van Wezel, 1972).

Third, OECD policymakers have also developed legislation regarding the commuting time and expect unemployed jobseekers to also search for and accept jobs that demand a certain, predetermined transportation time (Hasselpflug, 2005; Ministry of Finance, 1998; Venn, 2012). Several studies from the 1970s through the 1990s demonstrated that the majority of unemployed jobseekers (up to 54\%) are willing to accept jobs for which they have to commute extensively (Deleeck et al., 1988; Kloosterman, 1987; Kroft et al., 1989; Miltenburg \& Woldringh, 1990; Van Wezel, 1972). More recent research has also indicated that commuting time significantly influences jobseekers' decision to accept jobs (Boswell et al., 2003; Konrad et al., 2000; Turban, Forret \& Hendrickson, 1998).

\section{Predictors of flexible job search behaviour}

A first aim of this study is to examine possible antecedents of FJSB. Building on the career and HR literature, we expect that FJSB could be related to two opposing motivations. On the one hand, career scholars view FJSB as a manner to adapt successfully to changing career circumstances - such as being confronted with unemployment (e.g. Van den Broeck et al., 2010). In this respect, career adaptability could be a positive driver of FJSB. On the other hand, the HR literature suggests that people who search in a flexible way may feel pushed into FJSB due to more negative reasons, like, few labour market perspectives, social or financial pressure or a poor jobfit in the previous job. We elaborate on these potential driving forces below. 


\section{Positive driver of flexible job search behaviour}

In recent decades, the career landscape has been subjected to transformation: instead of traditional, steady career paths guided by the employer, employees are now presumed to hold selfdirected boundaryless careers, i.e. careers of which the onus rests on the employee and where physical boundaries are blurred and can easily be crossed (Arthur, 1994; Arthur \& Rousseau, 1996; Hall, 2004). In the notions of these boundaryless and self-directed careers, being able to adjust swiftly to different work and career circumstances is deemed indispensable (e.g. Hall, 2004; Koen et al., 2010; Mervish \& Hall, 1994). Or as Fugate et al. (2004) put it: "Survival in this turbulent career environment requires workers to continually manage change - in themselves and their contexts. Thus, a person's ability and willingness to adapt is essential to career success." In this respect, career adaptability has been given increased attention. This concept is defined as "an individual's ability to face, pursue, or accept changing career roles and to successfully handle career transitions" (Koen et al., 2010, p. 128). Moreover, it is often typified by mature contemplation, the willingness to alter behaviours, or the exploration of the self, the environment and possible career options (Savickas, 1997; Zikic \& Klehe, 2006; Zikic \& Saks, 2009).

Recent theorizing of career adaptability puts forward four adaptability resources (Savickas \& Porfeli, 2012). The first dimension is concern about the future, which stimulates people to look forward and to plan how to achieve their goals (e.g. finding a new job). The second dimension is control, which helps people to make their own decisions and to take responsibility for them. The third dimension is curiosity, which makes people explore different situations and investigate different career options. The last dimension is confidence; a career adaptable person should have confidence about performing his/her tasks (like a job search) well. People who score high on these 4C's are considered to proactively turn to self-regulation strategies when confronted with changing 
career circumstances, such as going from employment to unemployment. For people making the latter transition, career scholars believe that one of the successful self-regulating coping strategies is being open to different job opportunities and thus looking for jobs in a flexible way (e.g., Van den Broeck et al., 2010). FJSB is therefore seen as one of the ways people can deal with their changed career roles or the trauma of becoming unemployed. As such, career adaptability could be a positive driver of FJSB.

Hypothesis 1. Career adaptability is positively related to each dimension of flexible job search behaviour.

\section{Negative drivers of flexible job search behaviour}

People may also start searching in a flexible way because they feel pushed into it due to negative drivers. We examine four possible push factors: low reemployment prospects, social and financial pressure, and a low job-fit.

Reemployment efficacy could be a driver of FJSB. Reemployment efficacy refers to jobseekers perceived ability to find reemployment (Wanberg, Zhu, \& Van Hooft, 2010). If a jobseeker does not have much confidence in his chances on the labour market, he may set his standards for a new job lower and may therefore target a wider range of jobs, even jobs that are different in terms of previous working experience and educational background. Previous research demonstrates, for instance, that one's perceived reemployment chances reduces the demanded wage level in a new job (Christensen, 2001; Pannenberg, 2007).

Hypothesis 2a. Reemployment efficacy is negatively related to flexible job search behaviour. 
Next, experiencing social or financial pressure could act upon FJSB in a similar vein as reemployment efficacy. Jobseekers who are facing greater financial difficulties have a greater financial need to find work and will therefore often search more intensely in order to find a new job faster (Kanfer et al., 2001; Saks et al., 2005; Wanberg et al., 1999). Also the expectation of close friends or family members to find work (i.e., subjective norms) can provide additional pressure during the job search, which can also translate into a more vigorous search (Wanberg, Glomb, Song, \& Sorenson, 2005; Zikic \& Saks, 2009). Past research has demonstrated that people who experience more financial hardship or pressure from their close environment are more likely to develop an employment motive (van Dam \& Menting, 2012). Individuals with an employment motive want to find employment fast and are not very selective in their job search, since they consider unemployment as a negative experience which they want to end as quickly as they can. This seems to correspond with people who search in a flexible way. As such, financial hardship and subjective norms may be positively related to FJSB. We therefore expect a positive relationship between financial hardship and subjective norms on the one hand and the different types of flexible job search on the other, with one exception. That is, for the relationship between financial hardship and commuting search flexibility, we expect a negative impact. This is because those who struggle financially often also have less means for transportation (like owning a car), and may therefore be inclined to search a job closer to home.

Hypothesis 2b. Financial hardship is positively related to flexible job search behaviour with respect to pay/hierarchy and skills, and negatively related to commuting time flexible job search behaviour.

Hypothesis 2c. Subjective norms is positively related to flexible job search behaviour. 
Finally, people may also search in a flexible way due to previous negative job experiences. Job fit theory (Edwards, 1991; Kristof, 1996; Kristof-Brown et al., 2005) indicates that people evaluate the extent to which job demands coincide with their knowledge, skills, and abilities (ksa's). Moreover, people generally prefer to work in a job that match their ksa's (Boswell et al., 2003; Chapman et al., 2005; Taylor \& Bergmann, 1987; Turban, Eyring, \& Campion, 1993; Turban et al., 2001). Hence, when unemployed people experienced a poor job fit in their previous job, this may stimulate them to look for jobs that deviate from their past, less pleasing experiences.

\section{Hypothesis $2 d$. Job fit is negatively related to flexible job search behaviour.}

\section{Impact of flexible job search behaviour on reemployment success}

The second aim of this study is to examine the relationship between FJSB and reemployment success, in terms of reemployment likelihood and reemployment quality. Two opposing points of view stand out in this respect. On the one hand, policymakers and several career scholars presume that FJSB will ameliorate one's job search success. In particular, they believe that FJSB initiates a consecutive series of positive events leading to an increased likelihood to find a job (positive path of FJSB). On the other hand, HR-research advocating job-fit theories hints that individuals conducting FJSB will be confronted with more employer-oriented obstacles, reducing one's reemployment likelihood. Moreover, based on these theories, unemployed people flexible in their job search may also end up in poorer jobs in terms of reemployment quality (negative path of FJSB). Figure 1 gives an overview of the opposing positive and negative paths to reemployment likelihood.

\section{"(Figure 1 about here)"}

\section{A positive path}


Firstly, an important group of policymakers and career scholars postulate that flexibility may positively influence people's search effort and as such their chances of being hired (Grubb, 2001; Venn, 2012). That is, FJSB may increase one's reemployment likelihood through its positive impact on job search intensity which in turn increases the number of job interviews and job offers received. Job search intensity refers to the frequency with which jobseekers, during a set period of time, engage in specific job search activities, like visiting job websites, discussing job leads with friends and sending out resumés to prospective employers (Kanfer et al., 2001; Saks, 2006). Individuals who search in a flexible way in terms of pay/job level, skills or commuting time are less strict in their demand of a future job and take into account both jobs that are in line with as well as jobs that deviate from their previous job or studies on these respective aspects. Hence, they are likely to put in more time and effort to map all the different jobs they consider and use more diverse job search channels. For instance, being flexible with respect to commuting time implies also looking for jobs in a wider area. To identify these jobs therefore, additional search channels and effort may be needed, like using contacts all over the country, also looking at national newspapers or using broader search terms at job websites which may give more hits and therefore need more time to cover. Tapping more search channels and spending more time using them, both lead to a higher job search intensity (Kanfer et al., 2001). As job search intensity has been shown to enhance the number of job interviews (Bradley \& Taylor, 1992; Coté et al., 2006; Saks, 2006; Saks \& Ashfort, 2000), which in turn increases the number of job offers (Coté et al., 2006; Saks, 2006; Saks \& Ashforth, 2000) and the likelihood of reemployment (Coté et al. 2006), this would imply a positive path from FJSB to reemployment success.

Hypothesis 3a. Flexible job search behaviour is positively related to job search intensity.

Hypothesis 3b. Job search intensity is positively related to the number of job interviews. 
Hypothesis 3c. The number of job interviews is positively related to the number of job offers.

Hypothesis 3d. The number of job offers is positively related to the likelihood of job reemployment.

\section{A negative path}

Next to this positive path, there may also be a negative effect of FJSB on the number of job offers and the reemployment likelihood. Recent research demonstrates that unemployed individuals who adopt a flexible attitude (i.e., are "psychologically mobile") experience more barriers to getting a job offer (e.g., employers wanting more job related experience; feeling insecure during job interviews; Vansteenkiste et al., 2013). Indeed, as employers generally look for employees who fit well with the organisation and the vacant job and who have the right experience and aspirations (Bretz, Rynes, \& Gerhart, 1993; Judge \& Ferris, 1992), flexible applicants may be considered as an inferior match since they may lack the required skills or motivation. In addition, employers may believe that employees who are flexible in terms of pay/hierarchy, skills or commuting time, have not carefully pondered over their decision, and as such may regret or become dissatisfied with their decision in time (Aldag \& Power, 1986; Timmermans \& Vlek, 1994). Therefore, they may be reluctant in hiring them, believing that they have a higher likelihood of leaving the organization on their own initiative in the near future.

Hypothesis 4. Flexible job search behaviour relates negatively to the number of job offers.

Next, some career scholars are concerned that people who search in a flexible manner may end up in jobs of poorer quality (e.g. Van den Broeck et al., 2010). Since people's behaviours tend to affect their resulting situations (Lent, Brown, \& Hackett, 1994), we expect FJSB to impact job seekers' subsequent level of underemployment and as such their reemployment quality. If 
unemployed individuals are also looking for jobs that differ in terms of skill usage from their previous jobs or educational background, they may be more likely to end up in jobs that underutilize their skills (Côté, Saks, \& Zikic, 2006; Crossly \& Stanton, 2005; Saks, 2006; Saks \& Ashforth, 2000). Likewise, people looking for jobs that differ in terms of pay/hierarchy or commuting time from their previous jobs or educational background may more frequently end up in jobs that pay less or demand more commuting time. Having a substandard job has frequently been demonstrated to lead to experiencing a poorer job quality, in terms of, e.g., lower job satisfaction, higher turnover intentions, and lower levels of work engagement and person-job fit (Feldman, 1996; Feldman, Leana, \& Bolino, 2002; Maynard, Joseph, \& Maynard, 2006; Burke, 1997; Brasher \& Chen, 1999; McKee-Ryan et al., 2009; Johnson \& Johnson, 2000, among others). Individuals compare the features of their current jobs (e.g., wage, commuting time, content) to the features they feel entitled to given their background and the features of their former jobs (McKee-Ryan et al., 2009). If a discrepancy is observed, it gives rise to feelings of relative deprivation (e.g., McKee-Ryan et al. 2009; Erdogan \& Bauer, 2011; Feldman et al., 2002; Kraimer, Shaffer, \& Bolino, 2009). If people experience working in substandard jobs, they are likely to feel entitled to better jobs and to feel relatively deprived. In response to these feelings, such deprived employees may not feel like a part of these organizations and may therefore experience a lower person-job fit. In addition, they may "psychologically distance" themselves from their jobs and the organizations they work for, which may decrease their level of job satisfaction and work engagement and increase their intention to leave these organizations (Feldman et al., 2002; McKee-Ryan et al., 2009).

Hypothesis 5a. Flexible job search behaviour is positively related to underemployment. In particular, skill search flexibility is positively related to skill underutilization, pay/hierarchical search flexibility is positively related to pay/hierarchical 
underemployment and commuting search flexibility is positively related to commuting underemployment.

Hypothesis 5b. Underemployment leads to lower reemployment quality. Particularly, it gives rise to higher turnover intentions, lower job satisfaction, and lower levels of personjob fit and work engagement.

\section{Method}

\section{Procedures and Participants}

We collected two-wave longitudinal data in 2012 with short-term unemployed Flemish individuals who had a paid job before they became unemployed. This data-collection is part of a larger project. We targeted short-term jobseekers (i.e., at most four months unemployed) since in the beginning of the unemployment period, there is little pressure on job seekers in Flanders to accept jobs which are not in line with their preferences. Indeed, at the moment of the study, shortterm unemployed job seekers (i.e., at most six months unemployed) could refuse jobs of which the content was not in line with their preferences without any financial penalty. In addition, the National Employment Office (RVA or 'Rijksdienst voor arbeidsvoorziening') only held the first evaluation of the unemployed's searching behaviour after 15 months of unemployment at the earliest and unemployed individuals only risked losing their unemployment benefits for refusing jobs which were not in line with their preferences after 23 months of unemployment at the earliest. Therefore, respondents who were searching flexibly in our sample were likely to do it voluntarily, which is in line with our aim to examine the drivers and outcomes of voluntary flexible job search behavior.

Data were collected in collaboration with the Flemish public employment service (VDAB). Because every unemployed jobseeker in Flanders has to register with the VDAB, they have contact 
information of all unemployed individuals. They drew a random sample of 6000 short-term unemployed individuals, which we then contacted by e-mail or post. The first wave was conducted in October 2011 and reached 1743 respondents $\left(R R_{\mathrm{T} 1}=29 \%\right)$. After removing the respondents who were not actively looking for a new job $(N=412)$, we remained with a sample of 1331 respondents. The average age of these respondents was 38 years $(S D=10.71) ; 58 \%$ of them were female and $31 \%$ were lower educated (i.e. at most second stage of secondary education). Respondents had on average been unemployed for two months $(S D=1.50)$. We use this sample to test the hypotheses of the antecedents of FJSB.

The second wave, conducted three months later, resulted in 892 questionnaires (response rate of $67 \%)$. Respondents who were not actively looking for a new job $(N=56)$ and respondents with incomplete records on any of the variables under study $(N=164)$ were removed, leaving us with a sample of 672 respondents. The average age of these respondents was 39 years $(S D=10.39)$; $56 \%$ of them were female and $26 \%$ were lower educated (i.e., at most second stage of secondary education). We use this two-wave sample to test the hypotheses on the impact of FJSB on reemployment success.

We performed a drop-out analysis by using a multiple logistic regression where the dependent variable was a dummy indicating whether one responded or not at $\mathrm{T} 2$. The explanatory variables - all measured at $\mathrm{T} 1$ - were age, gender, ethnic origin, education, unemployment duration, FJSB with respect to pay/hierarchy, skills and commuting time, career planning, career resilience, career self-directedness, job search self-efficacy, subjective norms, financial hardship, reemployment efficacy, needs-supply fit in the previous job, previous wage, previous commuting time and job search intensity. We found that respondents at T2 were older, were more often female, had more financial hardship and searched more intensified than the non-respondents. Hence, we 
can conclude from this drop-out analysis that the attrition is not fully random, however, we found no differences in FJSB, the core variable of this study.

\section{Measures}

Responses of the scales discussed below were on a 5-point Likert scale ranging from 1 (strongly disagree) to 5 (strongly agree), unless indicated otherwise.

Flexible job search behaviour. To measure the three types of flexible job search behaviour, we started from existing scales on related constructs and adapted them slightly. First, pay/hierarchical search flexibility was measured using five items assessing the extent to which respondents (also) searched for jobs that paid less or were at a lower hierarchical level compared with their previous jobs or educational levels $(\alpha=0.81)$. The items were based on related scales from recent career and underemployment literature. We included two items on pay flexibility which were based on a scale of Van den Broeck et al. (2010) measuring a flexible attitude towards pay (sample item: "I am willing to accept a job that pays less well than usual, given my level of schooling"). We rewrote these two items in line with our focus on actual searching behaviour (e.g., we used the item "I (also) search for jobs which are underpaid, given my level of schooling"). We added the hierarchical dimension since pay and hierarchy are commonly seen as one scale in literature (see McKee-Ryan and Harvey, 2011) and also intertwined in the policy legislations concerning flexible searching. To this end, we drew on the article of McKee-Ryan and Harvey (2011) who give an overview of the underemployment literature and the ways in which different constructs have previously been measured. We included three items inspired by the scales of Aiken and Ferman (1966) and Feldman, Leana and Bolino (2002). A sample item of the hierarchical dimension is for instance "I (also) search for jobs which are at a lower level than my previous job", 
which is based on the item of Feldman et al. (2002), i.e., "My current job is at a much lower level than the one I had".

Skill search flexibility was measured with three items assessing the degree to which respondents (also) respond to jobs that are not in line with their previous jobs or studies $(\alpha=0.81)$. Our measure was inspired by the way job field underemployment is interpreted in underemployment literature. McKee-Ryan and Harvey (2011) describe the latter as working outside the field of formal education or training and refer to the measurement of Burke (1997). We took this up in our measurement, but also included a comparison with previous job content, as this is explicitly mentioned in flexibility legislation. As such, the scale consisted of the following three items: "I (also) search for jobs of which the content differs strongly from that of my previous job", "I (also) search for jobs that are not in line with my previous working experience" and "I (also) search for jobs that are not in line with my education or training".

Commuting search flexibility was measured with one item that assessed the degree to which respondents (also) search for jobs that have longer commuting times between home and work than their previous jobs. This is in line with most studies examining commuting, which use a one-item construct focusing on the commuting time or distance between home and work (e.g., Chapple, 2001; Clark, Huang, \& Withers, 2003; Gutiérrez-i-Puigarnau \& van Ommeren, 2010; Rouwendal, 2004; van Ommeren, Rietveld, \& Nijkamp, 1997, 1999). Participants indicated their response on all nine items on a 5-point Likert scale ranging from 1 (not at all) to 5 (definitely).

Given the newness of our measure, we performed several validity checks. First, checked the content and face validity of our measure. To safeguard the content validity, we developed the scale in different steps. First, we explored the literature on the flexible job search requirements which policy makers apply. This literature clearly points to three major dimensions of job search 
flexibility: content flexibility, pay and job level flexibility and commuting flexibility (e.g., Hasselpflug, 2005; Ministry of Finance, 1998; Venn, 2012). These were then the three dimensions we aimed to capture with our measurement. This contributes to one aspect of content validity, i.e., the extent to which the measure represents the different facets of a given construct. Next, since no existing scales existed on these three type of flexible job search behaviours, we searched for existing scales on content-wise related constructs (which were attitudinal, rather than behavioural), which we then reformulated in order to capture behaviour. We did so by looking at the formulations of validated and widely used job search behaviour measures, such as the job search intensity scale of Blau (1994). We then discussed these items with several experts (e.g. from the Flemish PES) and scholars in the field, which is another important step to support the content validity of a measure (Berk, 1990). To check the face validity of our measure, we then discussed the items with a number of unemployed persons, which is an accepted way to test this form of validity (Anastasi, 1988). Hence, both content an face validity checks were performed as suggested in the literature.

Second, to test the cross validation (i.e., the robustness of the factor structure of our scale) we performed a confirmatory factor analysis (CFA) on the second wave of the dataset (see table 1). The CFA shows that our three factor model has an acceptable fit $\left(\chi^{2}[24]=348.70 ; \mathrm{SRMR}=0.06\right.$; RMSEA $=0.11$ and CFI $=0.91)$ and performs significantly better than a one-factor or two-factor model.

\section{"(Table 1 about here)"}

Thirdly, we examined the discriminant validity of this measure by exploring whether our FJSB measure assessed something different than two other job search behaviours, i.e. job search intensity (one factor, measured with the scale of Blau, 1994 - see further) and job search strategy (three factors, measured with the scale of Crossly \& Highhouse, 2005). The job search strategy 
scale measures three types of search strategies, i.e. the haphazard strategy (i.e., not having a concrete plan when looking for a job), exploratory strategy (i.e., having several job options in mind and trying to gather as much information as possible of these different options from various sources) and the focused search strategy (i.e., having a limited number of job options in mind and guiding search efforts towards screening a limited number of vacancies and employers). To test the discriminant analyses of our measure, we performed a CFA on the nine items representing the three dimensions of FJSB, together with the 10 items representing job search intensity and the fifteen items representing the three different types of job search strategies. This model shows an acceptable fit: $\chi^{2}[423]=1530, p<.01 ; \operatorname{SRMR}=.06 ; \mathrm{RMSEA}=.05 ; \mathrm{CFI}=.91$. Table 2 also shows the correlation between each of these seven factors. All correlations are modest in size.

\section{“(Table 2 about here)"}

We also test the predictive validity of our measurement. Predictive validity refers to the extent that a (new) measurement is able to predict selected outcomes (Cronbach \& Meehl, 1955). In the paper we test the relationship between FJSB and outcomes like number of job offers, reemployment likelihood, underemployment and job quality. We discuss this results in the next section.

Career adaptability. We aimed to assess career adaptability by its four resources: concern, control, confidence and curiosity (Savickas \& Porfeli, 2012). However, the validated scales developed to measure these four dimensions have mostly been targeting people in labour or students (e.g. Dries et al., 2012), and are therefore not always suitable for people in unemployment. We therefore used scales for closely related constructs for each of the four Cs. We respectively used career planning as an indicator for concern (i.e., planning ahead), career self-directedness for control (i.e. take up responsibility for own decisions), job search self-efficacy for confidence (i.e. 
feeling confident to perform tasks well) and career resilience for curiosity (i.e. being open to new situations).

Career planning refers to having clear career goals and having a strategy to attain these goals (Gould, 1979; Zikic \& Klehe, 2006). Career planning was measured at T1 using the six-items scale of Gould (1979). A sample item is "I have a plan to obtain my career objectives". Reliability of this scale was .85 .

Career self-directedness points to the extent that people have the feeling to have control over their own career. It was measured at T1 by the scale of Briscoe, Hall and DeMuth (2006). A sample item is: "I am responsible for the success and failure of my career". The cronbach's alpha was .80.

Job search self-efficacy indicates the confidence unemployed persons have in executing their job search. We used the 10-item scale of Van Ryn and Vinokur (1992) to assess this at T1. The cronbach's alpha was .83 .

Career resilience refers to the extent to which people welcome changes in their career. It was assessed at T1 by using the scale of London (1993). A sample item is "To which extent do you welcome working with new people?". Respondents indicated their response on a 5-point scale (1 $=$ totally not $; 5=$ totally). The cronbach's alpha of this scale was .79 .

Job fit. Job fit in the previous job is indicated by needs-supply fit in the regression on skills FJSB, by the previous wage (in euros) in the regression on pay/hierarchical FJSB and by previous commuting time (in minutes) in the regression on commuting FJSB. Needs-supply fit in the previous job was measured by the 4-item scale developed by Resick, Baltes and Shantz (2007). Participants pointed out how well their previous job fitted their needs or desires. A sample item is, 
"My job fitted me well." Responses were given on a 5-point Likert scale, with 1 representing "totally disagree" and 5 representing "totally agree" $(\alpha=.94)$.

Reemployment efficacy. Consistent with Wanberg et al. (2010), we assessed reemployment efficacy at T1 using five items (e.g., "How easy or difficult do you expect it to be to find another job?"). Responses ranged from 1 (very difficult) to 5 (very easy). The Cronbach's alpha of this scale was .85 .

Subjective norms. Subjective norms were assessed at $\mathrm{T} 1$ by the 2 -item scale of Vinokur and Caplan (1987), which has been used extensively in previous research (e.g., Wanberg et al., 2005; Zikic \& Saks, 2009). A sample item is "Think about the person closest to you, such as a spouse, family member or good friend. How hard does this person think you should try to find a job in the next three months?". Answers were rated on a scale ranging from 1 (not hard at all) to 4 (extremely hard). Reliability of this scale was .85.

Financial hardship. Financial hardship was measured at T1 using the three-items scale of Vinokur and Caplan (1987), and Vinokur and Schul (1997) (e.g., "How difficult is it for you to live on your total household income right now?"). Responses were on a 5-point Likert scale (1 = not at all difficult; $5=$ extremely difficult). The Cronbach's alpha of this scale was .89 .

Job search intensity. Job search intensity was measured at T1 by the 9-item scale of Blau (1994), which has been extensively used in previous research (Coté et al., 2006; Saks \& Ashforth, 2000; Sverko, Galic, Sersic, \& Galesic, 2008; Van Hooft, Born, Taris, Van Der Flier, \& Blonk, 2004; Wanberg et al., 1999; Zikic \& Saks, 2009; amongst others). Participants indicated how frequently they used certain search sources or performed a variety of search behaviours during the last three months. Answers were given on a 5 -point Likert scale $(1=$ never, 0 times; $5=$ very often, 
at least 10 times). Sample items are e.g. "Reading job advertisements in the paper", "Contacting employment agencies", "Visiting job websites", "Discussing job leads with friends or relatives". The reliability of this scale was $\alpha=.82$.

Job search strategy. The three types of job search strategies were measured by the scale of Crossly \& Highhouse (2005). Three items were used to measure haphazard search strategy (e.g., "My approach to gathering job-related information could be described as random"), six items to measure exploratory search strategy (e.g., "I follow up on every lead to make sure that I don’t miss any golden opportunities") and six items to measure focused search strategy (e.g., "I gather information only for jobs that I am really interested in"). Responses were made on a 5-point Likert scale $(1=$ strongly disagree and $5=$ strongly agree $)$. The reliabilities of the respective scales were: $0.78 ; 0.82$ and 0.71 .

Quantitative job search success. Quantitative job search success was measured at T2 using three indicators, namely the number of job interviews received in the last three months, the number of job offers received in the last three months and a dummy variable indicating whether jobseekers found reemployment or not. All three measures have been extensively used in previous research as indicators of this type of job search success (e.g. Koen et al. 2010; Saks, 2006; Saks \& Ashforth, 2000).

Underemployment. Skill underutilization, was measured with three items based on the measurement of Caplan et al. (1975). The items assessed the degree to which respondents were able to utilize their knowledge and skills in their new jobs (e.g., "Often I cannot use the knowledge and skills that I have acquired through prior work experience in my current job.”). Pay/hierarchical underemployment was measured by assessing whether respondents were underpaid or working at a lower hierarchical level given their educational levels and previous work experience. Five items 
were used to assess this construct (e.g., "My current job pays less well than my previous one"; and "My current job has less responsibility than my previous one."). These items were based on the pay underemployment scale developed by Feldman et al. (2002) and the pay/hierarchical underemployment definition introduced by McKee-Ryan and Harvey (2011). Commuting underemployment was measured using one item that assessed whether participants had longer commuting times between home and work in their current jobs than in their previous jobs. Commuting underemployment is not a dimension that is often distinguished in underemployment research. However, since commuting generates significant psychological costs for the individual (see, e.g., Koslowsky, Kluger, \& Reich, 1995; Koslowsky, 1998), we believe that spending more time commuting could also be an important contributor to the experience of being underemployed. Indeed, like other underemployment factors, commuting is often considered a stressful experience that causes adverse emotional and physical reactions and has a negative impact on family life and health (Stutzer \& Frey, 2008).

Given the potential overlap between the different underemployment dimensions (McKeeRyan \& Harvey, 2011), we performed an EFA to determine the underlying dimensionality. The EFA with varimax rotation established the three factors. However, one item of skill underemployment had to be removed due to high factor loadings on two factors. The alphacoefficient of the skill underutilization and pay/hierarchical underemployment scales were .83 and .82 , respectively.

Job quality. We measured four indicators of job quality, namely needs-supply fit, job satisfaction, work engagement, and turnover intentions. These four indicators have been extensively used in previous underemployment and job search research as indicators of job quality (e.g., Anderson \& Winefield, 2011; Bolino \& Feldman, 2000; Erdogan \& Bauer, 2011; Maynard 
et al., 2006; McKee-Ryan \& Harvey, 2011). Needs-supply fit was assessed by the 4-item scale developed by Resick, Baltes, \& Shantz (2007). Participants pointed out how well their current jobs fit their needs or desires. A sample item is, "My job fits me well." Reliability of this scale was 0.93 . Job satisfaction was measured by one item based on Wanous, Reichers and Hudy (1997): "Taking all things together, how satisfied are you with your job?" on a 7-point Likert Scale (1= totally not satisfied and $7=$ totally satisfied). Results from Nagy (2002) demonstrate that a single-item measure for job satisfaction compares favourably with multiple-item measures. Work engagement was measured by nine items developed by Schaufeli, Bakker and Salanova (2006), e.g., "At my work, I feel bursting with energy," or "I am enthusiastic about my job." Responses were indicated on a five-point Likert Scale ranging from 1 ((almost) never) to 5 ((almost) always). Reliability of this scale was 0.95. Jiang and Klein's (2002) 3-item scale was used to measure turnover intentions. A sample item included, "I think a lot about leaving this organization." The alpha-coefficient was 0.95 .

Controls. We used age, gender, ethnic origin, educational level and unemployment duration as control variables in the regressions on the antecedents of FJSB. Previous studies have shown that these variables influence job search behaviour (e.g., Kanfer et al., 2001). Age, gender, ethnic origin, educational level, unemployment duration, job search strategies, employment commitment and job search self-efficacy were used as control variables in the regressions on job search success, since they have proven to significantly affect job search variables in previous research (e.g. Kanfer et al., 2001; Saks, 2005; Sverko et al., 2008; Vansteenkiste, Deschacht, \& Sels, 2015; Zikic \& Klehe, 2006). For instance, job search success has been found to decrease with increasing age and unemployment duration. Likewise, having a lower educational degree or being from a foreign origin has been found to impact job search success negatively. Moreover, higher 
levels of employment commitment and job search self-efficacy have been shown to impact jobseekers' search intensity positively.

\section{Results}

\section{Descriptive statistics}

In table 3 to 5, we present the descriptive statistics and correlations of the different variables under study. Table 3 shows the correlations between FJSB and the hypothesized positive and negative drivers. We first of all see that the average unemployed searched somewhat flexibly with respect to their skills $(M=3.08, S D=1.05)$, but rather inflexibly with respect to pay/hierarchy $(M$ $=2.31, S D=0.82)$ and with respect to commuting time $(M=2.27, S D=1.11)$. There are moderate positive correlations between the different types of flexibility $\left(r_{\text {pay/hierarchy and skills }}=.27 ; r_{\text {pay/hierarchy }}\right.$ and commuting $\left.=.30 ; r_{\text {skills and commuting }}=.19\right)$, suggesting that the three distinguished flexibility types are indeed distinct. We further see that the three types of FJSB correlate in a different way with different dimensions of career adaptability and the potential negative drivers of flexibility (see Table 3), which additionally supports the distinctiveness of the three types of FJSB.

\section{"(Insert Table 3 about here)"}

Table 4 shows the correlations between FJSB and quantitative reemployment success. Table 4 shows a positive correlation between each dimension of FJSB and job search intensity. That is, there is a positive correlation between job search intensity and respectively pay/hierarchical search flexibility $(r=.11, p<.01)$, skills search flexibility $(r=.15, p<.01)$ and commuting search flexibility $(r=.10, p<.05)$. Moreover, commuting search flexibility is positively related to the number of job interviews $(r=.10, p<.01)$, whereas pay/hierarchical and skills search flexibility are negatively related to the number of job offers (respectively $r=-.08, p<.05$ and $r=-.10, p<$ $.05)$. None of the three types of FJSB is significantly related to reemployment. 


\section{"(Insert Table 4 about here)"}

Table 5 shows the correlations between FSJB and reemployment quality. We see positive correlations between each dimension of FJSB and its corresponding dimension of underemployment. That is, there is a positive correlation between skill search flexibility and skill underutilization $(r=.23, p<.01)$, between pay/hierarchical search flexibility and pay/hierarchical underemployment $(r=.23, p<.01)$, and between commuting search flexibility and commuting underemployment $(r=.26, p<.01)$. The three dimensions of underemployment are negatively related to needs-supply fit, work engagement, and job satisfaction, and positively related to turnover intentions.

\section{“(Insert Table 5 about here)"}

\section{Antecedents of FJSB}

We test hypotheses 1 and $2 \mathrm{a}$ to $2 \mathrm{~d}$ using hierarchical linear regressions, presented in table 6. In the first step, we took up the control variables age, gender, origin, educational level and unemployment duration. In the second step, we included the four indicators of career adaptability. As can be noticed from table 6 , these indicators explain between $3 \%$ and $4 \%$ of the variance in FJSB $\left(\Delta R^{2}=.03\right.$ or $\left..04 ; p<.01\right)$. In the third and last step, the presumed negative drivers of FJSB were added. These variables were found to additionally explain between 1\% (pay/hierarchical FJSB) and 7\% (commuting FJSB) of the variance in FJSB.

Hypothesis 1 proposed that career adaptability would be positively related to FJSB. We used career planning, career resilience, career self-directedness and job search self-efficacy to represent the four dimensions of career adaptability (concern, curiosity, control and confidence). Table 6 indicates that there is indeed a positive relationship between career resilience and two types of FJSB $\left(\beta_{\text {skills }}=.17, p<.01 ; \beta_{\text {commuting }}=.18 ; p<.01\right)$. However, we find a negative relationship 
between career planning and pay/hierarchical FJSB $(\beta=-.12 ; p<.01)$ and skills FJSB $(\beta=-.13 ; p$ $<.01)$, and between career self-directedness and pay/hierarchical FJSB $(\beta=-.11 ; p<.01)$ and commuting FJSB $(\beta=-.08 ; p<.05)$. Job search self-efficacy is not significantly related to any of the FJSB types. Hence, we only find marginal support for hypothesis 1 .

\section{“(Insert Table 6 about here)"}

We find support for hypothesis $2 \mathrm{a}$ for one of the three FJSB dimensions: reemployment efficacy is negatively related to respectively pay/hierarchical search flexibility $(\beta=-.08 ; p<.05)$. Hypothesis $2 \mathrm{~b}$ proposed that financial hardship would be positively related to pay/hierarchical and skills search flexibility, and negatively to commuting search flexibility. We only find support for the negative relationship between financial hardship and commuting search flexibility $(\beta=-.08 ; p$ $<.01$ ); we cannot establish a significant relationship with the other two types of FJSB. This hypothesis is thus only partially supported. In line with hypothesis $2 \mathrm{c}$, we find subjective norms to be positively related with commuting search flexibility $(\beta=.10 ; p<.01)$; however, there is no significant relationship with pay/hierarchical or skills search flexibility. Therefore, also hypothesis $2 \mathrm{c}$ is only partly supported. With respect to hypothesis $2 \mathrm{~d}$, we indeed find that a better job fit in the previous job induces people to search less flexibly with respect to their skills and commuting time $\left(\beta_{\text {skills }}=-.20, p<.01 ; \beta_{\text {commuting }}=-.25, p<.01\right)$. However, as opposed to what we expected, there is a positive relationship between job fit and pay/hierarchical FJSB $(\beta=.10 ; p<.01)$.

\section{Impact of FJSB on quantitative job search success}

We used structural equation modelling (SEM) to test our model with two opposing effects of FJSB on quantitative job search success (McFatter, 1979). In our hypotheses, we argue that FJSB has positive mediated effects on job offers but negative direct effects. In the literature this has been referred to as 'inconsistent mediation' and is a form of suppression (MacKinnon, 
Fairchild, and Fritz, 2007). To test whether inconsistent mediation can be supported, we compare the fit-indices of our full mediation model (M1) with a model without the direct effect (M2), a model without effect from the causal variable to the mediator (M3) and a model without effect from the mediator to the outcome (M4). The results of this exercise can be found in table 7. This table shows that the full mediation model has an acceptable fit $\left(\chi^{2}[23]=26.28, p>.05\right.$; $\mathrm{SRMR}=.02$; RMSEA $=.02 ; \mathrm{CFI}=1.00)$ and performs significantly better than any of the other models.

\section{"(Insert Table 7 about here)"}

Next, we have a closer look at whether we find support for our hypothesized relationships. The results of the SEM-analyses can be found in figure 2. Hypothesis 3a expected a positive relationship between each form of job search flexibility and job search intensity. This hypothesis can only be supported for one of the types of FJSB. That is, only skills search flexibility $(\beta=.13$, $p<.01)$ is positively related to job search intensity.

\section{“(Insert Figure 2 about here)"}

Furthermore, in line with hypothesis $3 \mathrm{~b}$ to $3 \mathrm{c}$, a more intensified job search leads to a higher number of job interviews three months later $(\beta=.29, p<.01)$, which in turn has a positive effect on the number of job offers $(\beta=.27, p<.01)$. In line with hypothesis $3 \mathrm{~d}$, the number of job offers has a positive impact on reemployment $(\beta=0.37, p<.01)$.

Next to this positive path, the results also partly support the proposed negative impact of FJSB on the number of job offers (hypothesis 4$)$. Skills FJSB $(\beta=-.11, p<.01)$ and commuting FJSB $(\beta=-.08, p<.05)$ are negatively related to the number of job offers. We do not find a significant relationship between pay/hierarchical and the number of job offers. As such, we find only partial support for hypothesis 4 . 
To know which of the two paths, the negative or the positive path, is most decisive, we also have a look at the total effect of FJSB on the number of job offers and the reemployment likelihood. Overall, we found that the total effect of skills search flexibility on the number of job offers and the reemployment likelihood to be significantly negative $\left(\beta_{\text {job offers }}=-.10, p<.01 ; \beta_{\text {reemployment likelihood }}\right.$ $=-.04, p<.05)$. Similar results hold for commuting search flexibility $\left(\beta_{\text {job offers }}=-.08, p<.05\right.$; $\beta_{\text {reemployment likelihood }}=-.03, p<.05$ ). However, there is no significant total effect of pay/hierarchical or commuting FJSB on any of the quantitative job search success indicators.

\section{Impact of FJSB on reemployment quality}

We used structural equation modelling (SEM) to test the impact of FJSB on reemployment quality, as it allows multiple relationships to be tested simultaneously. We took up age, gender and job fit as control variables. The fit of this proposed model is acceptable: $\chi^{2}[52]=97.42, p=.00$; SRMR $=.04 ; \mathrm{RMSEA}=.07 ; \mathrm{CFI}=.95 ; \mathrm{NFI}=.91$. We also tested a model with extra relations from FJSB to job quality. The fit of this model is $\chi^{2}[49]=96.83, p=.00$; SRMR $=.04$; RMSEA $=$ $.07 ; \mathrm{CFI}=.95 ; \mathrm{NFI}=.91$. All the direct relationships from the indicators of FJSB to job quality are non-significant, indicating that a full-mediation model is more likely than a partial mediation model. Figure 3 shows standardized path estimates for the research model.

\section{"(Insert Figure 3 about here)"}

In hypothesis 5a, a positive relationship was expected between FJSB and underemployment. We find support for this hypothesis for all three types of FJSB on their corresponding types of underemployment. That is, skill search flexibility is positively related to skill underutilization $(\beta=$ $.21, p<.01) ;$ pay/hierarchical search flexibility is positively related to pay/hierarchical underemployment $(\beta=.25, p<.01)$, and commuting search flexibility is positively related to commuting underemployment $(\beta=.22, p<.01)$. 
Next, in line with hypothesis $5 \mathrm{~b}$, we establish that underemployment leads to more negative job quality in terms of lower needs-supply fit, job satisfaction, and work engagement, and higher turnover intentions. That is, skill underutilization, pay/hierarchical underemployment and commuting underemployment have a negative impact on job quality $\left(\beta_{\text {skill }}=-.13, p<.05\right.$; $\left.\beta_{\text {pay/hierarchy }}=-.52, p<.01 ; \beta_{\text {commuting }}=-.18, p<.01\right)$.

\section{Discussion}

In this study, we examined antecedents and outcomes of FJSB. Inspired by policy research and the literature on job design, job fit and willingness to sacrifice, we focused on three flexibility dimensions: pay/job level, skills and commuting search flexibility.

First, we tested the relationship between these three types of FJSB and job search antecedents. As FJSB is seen as a possible coping strategy to deal with unemployment (e.g. Van den Broeck et al., 2010), we first of all expected it to be more pronounced in persons who are highly adaptable in their career. Our results suggested, however, that career adaptable persons were not more inclined to search in a more flexible way. Having more concern about the future (i.e. being more involved in career planning), feeling more control over career decisions (i.e. being more selfdirected in one's career) or having more confidence to perform a good job search (i.e. having more job search self-efficacy) were not related with more FJSB; on the contrary, we sometimes even found a negative relationship. This could indicate that FJSB is not considered as a good coping strategy by adaptable unemployed individuals. In addition, we also expected that FJSB could be driven by more negative reasons, like seeing few labour market opportunities, feeling financial or social pressure or experiencing a bad job fit in the previous job. Financial and social pressure do not seem to drive people to search more flexibly with respect to pay or skills. As we investigated unemployed persons in the beginning of their unemployment period, it could be that they do not 
let themselves be influenced too much yet by external factors such as their environment and finances to search in a certain manner. This may be especially likely in Belgium, because replacement incomes during unemployment are relatively generous there. Experiencing few job opportunities, on the other hand, was related with more FJSB with respect to wage and skills. Perhaps, the number of available job opportunities is seen as a more permanent state and therefore as a greater pressure to take up jobs that demand a financial or skill-driven reorientation. We found opposite effects for commuting search flexibility. These opposite effects reinforce the idea that the three types of FJSB are distinct concepts, driven by other factors. Our results further suggest that FJSB with respect to skills and commuting time is indeed driven by a more negative fit in the previous job. However, a better paying job before becoming unemployed, makes people search more pay/hierarchical flexible, probably because these people have more leeway to lower their financial demands.

Next, we investigated whether higher FJSB leads to reemployment success. Our results showed that unemployed individuals who search in a more flexible way with respect to their skills search more intensely and as a result receive more invitations to the selection process. The latter was found to increase the number of job offers and the likelihood of reemployment. However, for skills and commuting search flexibility there is also an opposing force at work which negatively impacts the number of job offers and hence, offsets the increased likelihood of reemployment. Moreover, when we looked at the total effect of these flexibility types, we found that searching more flexible with respect to ones skills or commuting time results in a total negative impact on the number of received job offers and the reemployment likelihood. Furthermore, we did not find an impact of searching flexibly regarding pay/job level on any quantitative job search success outcome. This null-effect may be explained by the fact that jobseekers who apply for jobs that are below their previous wage or job level are more often overskilled for the job, which may be less a 
problem from an employer point of view since overskilled employees need less additional education or training. Anyway, our results contradict the positive expected effects of both policymakers and scholars (e.g., Venn, 2012; Van den Broeck et al., 2010) and raises questions as to the effectiveness of policies imposing flexibility in the job search of the unemployed.

In addition to sometimes hampering one's reemployment chances, we found that higher levels of flexible job searching lead to a higher chance of ending up in underemployment, which in turn results in experiencing a more negative job quality. Experiencing a more negative job quality may induce individuals to leave their jobs and become unemployed again. In this way, a more flexible job search could cause one to obtain a less sustainable job and career path. Hence, our results point to important caveats that should be included in further thinking about flexibility during unemployment by both policymakers and scholars, at least in the beginning of the unemployment period.

\section{Implications for theory}

This study first of all adds important insights to the job search literature. Up to now, most studies examining job search behaviour focused on job search intensity, i.e. the frequency with which jobseekers, during a set period of time, perform certain job search activities, like visiting job websites, discussing job leads with friends, etc. (Kanfer et al., 2001; Saks, 2005). Even though this type of job search behaviour has proven to be an important predictor of reemployment outcomes (see Kanfer et al., 2001 and Saks, 2005 for an overview), it is presumed that this only forms the tip of the iceberg and that much can be gained from adopting a broader approach to job search behaviour (Koen et al. 2010; Saks \& Ashforth, 2002). In particular, scholars have called to introduce and study new indicators of job search behaviour (Koen et al., 2010; Saks \& Ashforth, 2002). By focusing on FJSB, we answered this call. Moreover, we demonstrated that it is useful to 
conceptualize this type of job search behaviour as a multidimensional measure. Though the three forms of FJSB are related, they are not always influenced by the same antecedents nor do they all have the same effects on the job search outcomes. Next, we studied career variables in a job search context. Only recently scholars have started to link career attitudes to job search behaviours (e.g., Zikic \& Saks, 2009; Koen et al., 2010). Future research could benefit from adopting a similar approach, as both our study and the one of Koen and colleagues (2010) shows that career variables are able to significantly predict job search behaviours.

This study also adds to the career literature. In the notion of protean careers, people are increasingly deemed responsible for developing their own career (Hall, 2004; King, 2004). In this respect, it is often believed that people can take matters into their own hands and can control their future by just conducting the proper behaviours. As such, the emphasis is principally on agencyfactors and less on structural factors (Forrier, Sels, \& Stynen, 2009). In this vein, flexibility is believed to be a suitable behaviour as it may enable unemployed jobseekers to adjust better to their new context of unemployment and may let them find reemployment more easily. However, our results indicate that flexibility is not always rewarded in the job search process, suggesting that unemployed individuals are also subject to structural components, i.e., circumstances beyond their control. Moreover, it also shows that searching flexibly is not always the best way to deal with a period of unemployment, even though it is believed to be one of the key behaviours in new career thinking (Hall, 2004; Koen et al., 2010; Mervish \& Hall, 1994).

This study also makes valuable contributions to the underemployment literature. We used underemployment as a mediator in our model on the relationship between FJSB and job quality. As such, we found support for the relationship between search behaviour and job quality, which had previously remained weak at best (Koen et al., 2010; Saks, 2005; Saks \& Ashforth, 2002; 
Wanberg et al., 2002). Moreover, by linking underemployment and job search behaviour, we also examined how people end up in substandard jobs, which has rarely been investigated (Feldman, 1996; Maynard, 2011). Furthermore, we considered commuting underemployment as one of the dimensions of underemployment. To date, commuting underemployment has been neglected in underemployment research, even though commuting has proven to generate significant psychological costs for the individual (see, e.g., Koslowsky et al., 1995; Koslowsky, 1998; Stutzer \& Frey, 2008). As we found commuting underemployment to have similar negative consequences on work-related attitudes and well-being as the other types of underemployment, it could be interesting for future underemployment research to include this additional dimension.

\section{Implications for policy and practice}

Policymakers take a positive stance towards unemployed individuals' flexibility and expect that it will increase their chances of acquiring new jobs. We demonstrated that there are also downsides of searching flexibly during the job search process, in terms of reemployment likelihood and quality. We therefore believe that the results of this study demonstrate that one should be cautious with promoting people to search flexibly and at least provide extra guidance to flexible jobseekers. In particular, there may be an important role for counsellors in helping unemployed jobseekers to find a new job. Firstly, it may be worthwhile to let job counsellors advise jobseekers not to go for every possible job or not to burn energy on job opportunities which are likely to fail anyway (cf. Vansteenkiste et al. 2013). At least in the beginning of the unemployment period, our results show that it may be more interesting to not search too widely with respect to skills or commuting time, but more or less in the direction of the previous job, since this is likely to be more valued by potential employers. Indeed, employers may prefer applicants who search for jobs that are in line with their previous employment experience. They may fear that hiring a highly flexible 
person in terms of skills or commuting time could jeopardize the person-environment fit and increase the risk of turnover. From a policy point of view, it is rather remarkable that individuals actively looking for jobs in other job domains and thus willing to reorient, are less often granted the opportunity to do so, especially in a context where a lot of employers complain of having difficulties to fill certain job vacancies (European Commission, 2012). Several reasons are possible for this finding. Firstly, our results seem to suggest that people flexible in their job search sometimes lack the confidence, control and concern about their career, which possibly makes them come across as less convincing and motivated towards future employers. In this respect, it is important to offer adequate guidance so that these flexible jobseekers come across as confident and motivated, and are able to convince employers of their willingness to perform the job and to take away any possible concerns regarding their sustainable employability in the organisation. Secondly, our finding that jobseekers who are willing to reorient hamper their reemployment chances could also suggest that part of the problem lies with the stringent selection processes employers use. Cappelli (2012) dedicated a whole book on this subject and came to the conclusion that even when vacancies are difficult to fill, employers still make unrealistic and excessive demands as to working experience, previous job titles,... towards potential employees. Our results could point towards a similar problem.

Although we found several negative effects of FJSB, it is not fully clear yet whether this type of behaviour should be totally discouraged. For instance, it is possible that the "choice" to accept a less-than-ideal job is temporary and that it should be seen as a stepping stone towards a better and more sustainable job. Prolonged research is needed to determine whether these poorer quality jobs are indeed a stepping stone or rather a trap. Furthermore, our results were only tested within a group of short-term unemployed. It is uncertain whether our results are also applicable on 
unemployed with a longer unemployment duration. It is possible that after a certain unemployment duration the negative effects of flexibility become less pronounced or, conversely, are reversed. Further research could examine this in more debt and investigate whether e.g. a certain protection period - i.e., a period wherein the unemployed can search linearly - should be encouraged and how long this protection period should optimally be. In this respect, it could be very useful to repeat this research with a mixture of short-term and long-term unemployed individuals and to look in more detail at the impact of the unemployment duration on the outcomes presented in this study.

On the basis of this study, then, we would discourage policymakers to enforce a flexible job search behaviour on short-term unemployed. Indeed, especially in the beginning of one's unemployment, policymakers should be cautious with promoting or obliging people to search flexibly and keep in mind that his type of search can have negative effects both on the reemployment likelihood and reemployment quality.

\section{Limitations and directions for future research}

Aside from the fact that we focused on relatively short-term unemployed individuals and therefore cannot yet translate our results to long-term unemployed, there are some additional limitations connected with this study, which could be addressed in future research. First, institutional factors could play a role. For instance, in countries were the system of unemployment benefits is less generous (i.e. shorter duration and/or lower level of benefits), the pressure to accept just any kind of job may be bigger and hence the impact of flexible job search behaviour may be different. It may therefore be interesting to go deeper into the influence of institutional systems on the impact of searching flexibly. Moreover, we studied respondents who were not much pressurized by the public employment agency to search flexibly. Future research could scrutinize the impact of searching in a flexible way when this is strictly forced upon by policy requirements. 
Second, as this study was conducted in Flanders, it is possible that cultural factors influenced our results. For example, although Belgium is a rather small country, most Belgians want short commutes between home and work (OECD, 2011). It is therefore possible that commuting underemployment has a stronger negative effect on job quality than in countries with a stronger commuting culture. Future research could therefore examine the effect of different cultural influences on our model.

Third, the measure we used for FJSB should be further tested in and if necessary adapted to different contexts. For instance, depending on the policy context, additional items to this measurement could be in place. It could, for instance, be argued that commuting flexibility should not only be about time you spend travelling (which we measured), but also about wanting to relocate. We did not include relocation since Belgium (the country were the study took place) is a very small country and relocating is not something that is taken up in national policy towards unemployed, nor is it something which appears to happen frequently in this country (see higher). However, in larger countries - and depending on their legislation - it could be relevant to add an item that measures the degree to which people also search for jobs that would require them to move or relocate.

Fourth, we only focused on three types of FJSB, inspired by existing policy regulations and several research streams. Future research could identify and study other types of flexibility, such as flexibility with respect to working hours, vacation time, work/non-work balance, etc.

Fifth, there were only three months between when we measured the antecedents and the outcomes. Using a longer time frame could give better indications of the sustainability of newly acquired jobs. This could for instance allow to examine whether the observed negative effects on job quality become even more prominent with time. 


\section{Conclusion}

In this study, we focused on flexible job search behaviour among unemployed jobseekers. This type of behaviour has been promoted and encouraged by both policymakers and scholars, but rarely been investigated up to now. As such, this study made an important contribution to the job search literature and to existing policy insights. This study has also some practical implications, since it demonstrates that people who search in a more flexible way do not increase their reemployment likelihood and may even hamper it in case of searching more flexibly with respect to skills or commuting time. Moreover, for those unemployed who do find reemployment, a more flexible job search results in experiencing the new job as of poorer quality. These findings go against some of the prevailing assumptions made by policymakers and scholars. Hence, this study points out that flexible job search behaviour among unemployed jobseekers does not achieve the anticipated results, indicating the necessity of rethinking policies aimed at promoting this type of behaviour.

\section{References}

Aiken, M, \& Ferman, L. (1966). Job mobility and the social integration of displaced workers. Social Problems, 14, 48-56.

Aldag, R., \& Power, D. (1986). An empirical assessment of computer-assisted decision analysis. Decision Sciences, 17, 572-588.

Anderson, S., \& Winefield, A.H. (2011). The impact of underemployment on psychological health, physical health, and work attitudes. In Maynard, D. \& Feldman, D. (Eds.) Underemployment. Psychological, economic and social challenges (pp. 165-185). Springer Science and Business Media. 
Arthur, M. (1994). The boundaryless career: a new perspective for organizational inquiry. Journal of Organizational Behavior, 15(4), 295-306.

Arthur, M., \& Rousseau, D. (1996). The boundaryless career: a new employment principle for a new organizational era. New York: Oxford University Press.

Blau, G. (1994). Testing a two-dimensional measure of job search behavior. Organizational Behavior and Human Decision Processes, 59, 288-312.

Bolino, M., \& Feldman, D. (2000). The antecedents and consequences of underemployment among expatriates. Journal of Organizational Behavior, 21, 889-911.

Boswell, W., Roehling, M., LePine, M., \& Moynihan, L. (2003). Individual job-choice decisions and the impact of job attributes and recruitment practices: a longitudinal field study. Human Resource Management, 42, 23-37.

Bradley, S., \& Taylor, J. (1992). An empirical analysis of the unemployment duration of school leavers. Applied Economics, 24, 89-101.

Brasher, E., \& Chen, P. (1999). Evaluation of success criteria in job search: A process perspective. Journal of Occupational and Organizational Psychology, 72, 57-70.

Bretz, R., Rynes, S., \& Gerhart, B. (1993). Recruiter perceptions of applicant fit: implications for individual career preparation and job search behavior. Journal of Vocational Behavior, 43, 310-327.

Briscoe, J., Hall, D., \& DeMuth, F. (2006). Protean and boundaryless careers: An empirical exploration. Journal of Vocational Behavior, 69, 30-47.

Burke, R. (1997). Correlates of under-employment among recent business school graduates. International Journal of Manpower, 18, 627-635. 
Cappelli, P. (2012). Why good people can't get jobs : the skills gap and what companies can do about it. Wharton Digital Press.

Caplan, R., Cobbs, S., French, J., Harrison, R., \& Pinneau, S. (1975). Job demands and worker health. US Department of Health, Education \& Welfare.

Chapman, D., Uggerslev, K., Carroll, S., Piasentin, K., \& Jones, D. (2005). Applicant Attraction to Organizations and Job Choice: A Meta-Analytic Review of the Correlates of Recruiting Outcomes. Journal of Applied Psychology, 90, 928-944.

Chapple, K. (2001). Time to work: Job search strategies and commute time for women on welfare in San Francisco. Journal of Urban Affairs, 23, 155-173.

Christensen, B. (2001). The determinants of reservation wages in Germany. Kiel Working Paper No. 1024, Kiel Institute of World Economics, Kiel, Germany.

Clark, W., Huang, Y., \& Withers, S. (2003). Does commuting distance matter? Commuting tolerance and residential change. Regional Science and Urban Economics, 33, 199-221.

Côté, S., Saks, A., \& Zikic, J. (2006). Trait affect and job search outcomes. Journal of Vocational Behavior, 68, 233-252.

Crossley, C., \& Highhouse, S. (2005). Relation of job search and choice process with subsequent satisfaction. Journal of Economic Psychology, 26, 255-268.

Crossley, C., \& Stanton, J. (2005). Negative affect and job search: Further examination of the reverse causation hypothesis. Journal of Vocational Behavior, 66, 549-560.

Deleeck, H., Van Hoye, R., Janssens, E., \& Peeters, J. (1988). De determinanten van de herintrede op de arbeidsmarkt. Centrum voor Sociaal Beleid, Universiteit Antwerpen. 
Dries, N., Van Esbroeck, R., van Vianen, A., De Cooman, R., \& Pepermans, R. (2012). Career Adapt-Abilities Scale-Belgium Form: Psychometric characteristics and construct validity. Journal of Vocational Behavior, 80, 674-679.

Eby, L., Butts, M., \& Lockwood, A. (2003). Predictors of success in the era of the boundaryless career. Journal of Organizational Behavior, 24, 689-708.

Edwards JR. (1991). Person-job fit: A conceptual integration, literature review, and methodological critique. In Cooper CLRIT (Ed.) International review of industrial and organizational psychology (Vol. 6, 283-357). Chichester, UK: Wiley.

Erdogan, B., \& Bauer, T.N. (2011). The impact of underemployment on turnover and career trajectories. In D. Maynard \& D. Feldman (Eds.) Underemployment. psychological, economic and social challenges (pp. 215-232). Springer Science and Business Media.

European Commission (2012). European Vacancy and Recruitment Report 2012. Luxembourg: Publications Office of the European Union.

Feldstein, M., \& Poterba, J. (1984). Unemployment insurance and reservation wages. Journal of Public Economies, 23, 141-167.

Feldman, D. (1996). The nature, antecedents and consequences of underemployment. Journal of management, 22, 385-407.

Feldman, D., Leana, C., \& Bolino, M. (2002). Underemployment and relative deprivation among reemployed executives. Journal of Occupational and Organizational Psychology, 75, 453471. 
Forrier, A., Sels, L., \& Stynen, D. (2009). Career mobility at the intersection between agent and structure: A conceptual model. Journal of Occupational and Organizational Psychology, 82, 739-759.

Fugate, M., Kinicki, A., \& Ashforth, B. (2004). Employability: A psycho-social construct, its dimensions, and applications. Journal of Vocational Behavior, 65, 14-38.

Gould, S. (1979). Characteristics of career planners in upwardly mobile occupations. Academy of Management Journal, 22, 539-550.

Grubb, D. (2001). Eligibility Criteria for Unemployment Benefits. In: OECD, Labour Market Policies and the Public Employment Service, 187-216.

Gutiérrez-i-Puigarnau, E., \& van Ommeren, J. (2010). Labor supply and commuting. Journal of Urban Economics, 68, 82-89.

Hall, D. (2004). The protean career: a quarter-century journey. Journal of Vocational Behavior: $65,1-13$

Hasselpflug, S. (2005). Availability Criteria in 25 Countries. Danish Ministry of Finance Working Paper, 12, Copenhagen.

Hogan, V. (2004). Wage aspirations and unemployment persistence. Journal of Monetary Economics, 51, 1623-1643.

Jiang, J. J., \& Klein, G. A. (2002). A discrepancy model of information system personnel turnover. Journal of Management Information Systems, 19, 249-262.

Johnson, G., \& Johnson, W. (2000). Perceived overqualification, positive and negative affectivity, and satisfaction with work. Journal of Social Behavior and Personality, 15, 167-184. 
Jones, S. (1989). Reservation wages and the cost of unemployment. Economica, 56, 225-246.

Judge, T., \& Ferris, G. (1992). The elusive criterion of fit in human resources staffing decisions. Human Resource Planning, 5, 47-67.

Kanfer, R., Wanberg, C., \& Kantrowitz, T. 2001. Job search and reemployment: A personalitymotivational analysis and meta-analytic review. Journal of Applied Psychology, 86, 837-855.

Kloosterman, R. (1987). Achteraan in de rij. Een onderzoek naar de factoren die (her)intreding van langdurig werklozen belemmeren: Deel I. Rapport en Deel 2. Bijlagen. ' Gravenhage: Organisatie voor Strategisch arbeidsmarktonderzoek.

Koen, J., Klehe, UC., Van Vianen, A., Zikic, J., \& Nauta, A. (2010). Job-search strategies and reemployment quality. The impact of career adaptability. Journal of Vocational Behavior, 77, 126-139.

Konrad, A., Edgar, R., Lieb, P., \& Corrigall, E. (2000). Sex differences and similarities in job attribute preferences: a meta-analysis. Psychological Bulletin, 126, 593-641.

Koslowsky, M. (1998). Commuting and Mental Health. In H. S. Friedman (Ed.). Encyclopedia of Mental Health, vol. 1. (pp. 521-530). New York: Academic Press.

Koslowsky, M., Kluger, A., \& Reich, M. (1995). Commuting stress: Causes, effects, and methods of coping. New York: Plenum Press.

Kraimer, M., Shaffer, M., \& Bolino, M. (2009). The influence of expatriate and repatriate experiences on career advancement and repatriate retention. Human Resource Management, $48,27-47$.

Kristof A. (1996). Person-organization fit: An integrative review of its conceptualizations, measurement, and implications. Personnel Psychology, 49, 1-49. 
Kristof-Brown, A., Zimmerman, R., \& Johnson, E. (2005). Consequences of individuals` fit at work: a meta-analysis of person-job, person-organization, person-group, and personsupervisor fit. Personnel Psychology, 58, 281-342.

Kroft, H., Engbersen, G., Schuyt, K., \& Van Waarden F. (1989). Een tijd zonder werk. Een onderzoek naar de levenswereld van langdurig werklozen. Leiden: Stenfert Kroese.

Kulik, C., Roberson, L., \& Perry, E. (2007). The multiple-category problem: category activation and inhibition in the hiring process. Academy of Management Review, 32, 2, 529-548.

Lawler, E. (1994). From job-based to competency-based organizations. Journal of Organizational Behavior, 15, 3-15.

Lent, R. Brown, S., \& Hackett, G. (1994). Toward a unifying social cognitive theory of career and academic interest, choice, and performance. Journal of Vocational Behavior, 45, 79-122.

London, M. (1993). Relationship between career motivation, empowerment and support for career development. Journal of Occupational and Organizational Psychology, 66, 55-69.

MacKinnon, D., Fairchild, A., \& Fritz, M. (2007). Mediation analysis. Annual Review of Psychology, 58, 593-614.

Maynard, D., Joseph, T., \& Maynard, A. (2006). Underemployment, job attitudes, and turnover intentions. Journal of Organizational Behavior, 27, 509-536.

McFatter RM. (1979). The use of structural equation models in interpreting regression equations including suppressor and enhancer variables. Applied Psychological Measurement, 3, 123135.

McKee-Ryan, F., \& Harvey, J. (2011). “I have a job, but...”: A review of underemployment. Journal of Management, I, 962-996. 
McKee-Ryan, F., Virick, M., Prussia, G., Harvey, J., \& Lilly, J. (2009). Life after the layoff: Getting a job worth keeping. Journal of Organizational Behavior, 30, 561-580.

Mervish, P., \& Hall, D. (1994). Psychological success and the boundaryless career. Journal of Organizational Behavior, 15, 365-380.

Miltenburg, T., \& Woldringh, C. (1989). Langdurige werkloosheid. Een onderzoek bij jongeren van 18-22 en mannen van 30-44 jaar. Nijmegen: Instituut voor toegepaste sociale wetenschappen.

Ministry of Finance (1998). Availability Criteria in Selected OECD-Countries. Danish Ministry of Finance Working Paper, 6, Copenhagen.

Nagy, M. (2002). Using a single-item approach to measure facet job satisfaction. Journal of Occupational and Organizational Psychology, 75, 77-86.

OECD (2011). OECD Family Database, OECD, Paris.

Osborn, D. P. (1990). A reexamination of the organizational choice process. Journal of Vocational Behavior, 36, 45-60.

Pannenberg, M. (2007). Risk aversion and reservation wages. IZA Discussion Paper No. 2806, Institute for the Study of Labor, Bonn, Germany.

Peiró, J., García-Montalvo, J. \& Gracia, F. (2002). How Do Young People Cope With Job Flexibility? Demographic and Psychological Antecedents of the Resistance to Accept a Job with Non-Preffered Flexibility Features. Applied Psychology: An International Review, 51, 43-66. 
Resick C., Baltes, B., \& Shantz, C. (2007). Person-organization fit and work-related attitudes and decisions: Examining interactive effects with job fit and conscientiousness. Journal of Applied Psychology, 92, 1446-1455.

Rousseau, D. (1997). Organizational behavior in the new organizational era. Annual Review of Psychology, 48, 515-546.

Rouwendal, J. (2004). Search theory and commuting behavior. Growth and Change, 35, 391-418.

Saks, A. (2005). Job search success: A review and integration of the predictors, behaviors and outcomes. In S. Brown \& R. Lent (eds.), Career development and counseling: Putting theory and research to work, 155-179. Hoboken, New Jersey: John Wiley \& Sons, Inc.

Saks, A. (2006). Multiple predictors and criteria of job search success. Journal of Vocational Behavior, 68, 400-415.

Saks, A., \& Ashforth, B. (2000). Change in job search behaviors and employment outcomes. Journal of Vocational Behavior, 56, 277-287.

Saks, A., \& Ashforth, B. (2002). Is job search related to employment quality? It all depends on the fit. Journal of Applied Psychology, 87, 646-654.

Savickas, M. (1997). Career adaptability: an integrative construct for life-span, life-space theory. The career development quarterly, 45, 247-259.

Savickas, M., \& Porfeli, E. (2012). Career Adapt-Abilities Scale: Construction, reliability, and measurement equivalence across 13 countries. Journal of Vocational Behavior, 80, 661-673.

Schaufeli, W., Bakker, A., \& Salanova, M. (2006). The measurement of Work Engagement with a Short Questionnaire. Educational and Psychological Measurement, 66; 701-716Stutzer, A., 
\& Frey, B. (2008). Stress that doesn't pay: The commuting paradox. Scandinavian Journal of Economics, 110, 339-366.

Sverko, B., Galic, Z., Sersic, D., \& Galesic, M. (2008). Unemployed people in search of a job: reconsidering the role of search behavior. Journal of Vocational Behavior, 72, 415-428.

Taylor, M., \& Bergmann, T. (1987). Organizational recruitment activities and applicants' reactions at different stages of the recruitment process. Personnel Psychology, 40, 261-285.

Timmermans, D., \& Vlek, C. (1994). An evaluation study of the effectiveness of Multi-attribute decision support as a function of problem complexity. Organizational Behavior and Human Decision Processes, 59, 75-92.

Turban, D., Eyring, A., \& Campion, J. (1993). Job attributes: preferences compared with reasons given for accepting and rejecting job offers. Journal of Occupational and Organizational Psychology, 66, 71-81.

Turban, D., Forret, M., \& Hendrickson, C. (1998). Applicant attraction to firms: Influences of organizational reputation, job and organizational attributes and recruiter behaviors. Journal of Vocational Behavior, 52, 24-44.

Turban, D., Lau, C., Ngo, H., Chow, I., \& Si, S. (2001). Organizational attractiveness of firms in the People's Republic of China: A person- organization fit perspective. Journal of Applied Psychology, 86, 194-206.

van Dam, K., \& Menting, L. (2012). The role of approach and avoidance motives for unemployed job search behavior. Journal of Vocational behavior, 80, 108-117. 
Van den Broeck, A., Vansteenkiste, M., Lens, W., \& De Witte, H. (2010). Unemployed individuals' work values and job flexibility: an explanation from expectancy-value theory and self-determination theory. Applied Psychology: An International Review, 59, 296-317.

Van Hooft, E., Born, M., Taris, T., Van Der Flier, H., \& Blonk, R. (2004). Predictors of job search behavior among employed and unemployed people. Personnel Psychology, 57, 25-59.

van Ommeren, J., Rietveld, P., \& Nijkamp, P. (1997). Commuting: In search of jobs and residences. Journal of Urban Economics, 42, 402-421.

van Ommeren, J., Rietveld, P., \& Nijkamp, P. (1999). Job moving, residential moving, and commuting: A search perspective. Journal of Urban Economics, 46, 230-253.

Van Ryn, M., \& Vinokur, A. D. (1992). How did it work? An examination of the mechanisms through which an intervention for the unemployed promoted job-search behavior. American Journal of Community Psychology, 20, 577-597.

Vansteenkiste, S. (2014). Does flexibility work for the workless? Examining the impact of a flexible job search among unemployed jobseekers. PhD Dissertation, KU Leuven.

Vansteenkiste, S., Deschacht, N. \& Sels, L. (2015). Why are unemployed aged fifty and over less likely to find a job? A decomposition analysis. Journal of Vocational Behavior, 90, 55-65.

Vansteenkiste, S., Verbruggen, M., \& Sels, L. (2013). Being unemployed in the boundaryless career era: Does psychological mobility pay off? Journal of Vocational Behavior, 82, 135 143.

Van Wezel, J. (1972). Herintreding in het arbeidsproces: een onderzoek onder werklozen. Giannotten, Tilburg. 
Venn, D. (2012). Eligibility Criteria for Unemployment Benefits: Quantitative indicators for OECD and EU Countries. OECD Social, Employment and Migration Working Papers, 131. OECD Publishing.

Vinokur, A., \& Caplan R. (1987). Attitudes and social support: Determinants of job-seeking behavior and well-being among the unemployed. Journal of Applied Social Psychology, 17, 1007-1024.

Vinokur, A., \& Schul, Y. (1997). Mastery and inoculation against setbacks as active ingredients in the JOBS intervention for the unemployed. Journal of Consulting and Clinical Psychology, $65,867-877$.

Wanberg, C., Glomb, T., Song, Z., \& Sorenson, S. (2005). Job-Search Persistence During Unemployment: A 10-Wave Longitudinal Study. Journal of Applied Psychology, 90, 411430.

Wanberg, C., Hough, L., \& Song, Z. (2002). Predictive validity of a multidisciplinary model of reemployment success. Journal of Applied Psychology, 87, 1100-1120.

Wanberg, C., Kanfer, R., \& Rotundo, M. (1999). Unemployed individuals: Motives, job-search competencies, and job-search constraints as predictors of job seeking and reemployment. Journal of Applied Psychology, 84, 897-910.

Wanberg, C., Zhu, J., \& van Hooft, E. (2010). The job search grind: Perceived progress, selfreactions, and self-regulation of search effort. Academy of Management Journal, 53, 788807.

Wanous, J., Reichers, A., \& Hudy, M. (1997). Overall job satisfaction: How good are single-item measures? Journal of Applied Psychology, 82, 247-252. 
Zikic, J., \& Klehe, U. (2006). Job loss as a blessing in disguise: the role of career exploration and career planning in predicting reemployment quality. Journal of Vocational Behavior, 69, 391-409.

Zikic, J., \& Saks, A. (2009). Job search and social cognitive theory: The role of career-relevant activities. Journal of Vocational Behavior, 74, 117-127. 
Figure 1. Hypothesized model between flexible search behavior, search intensity and job search success.

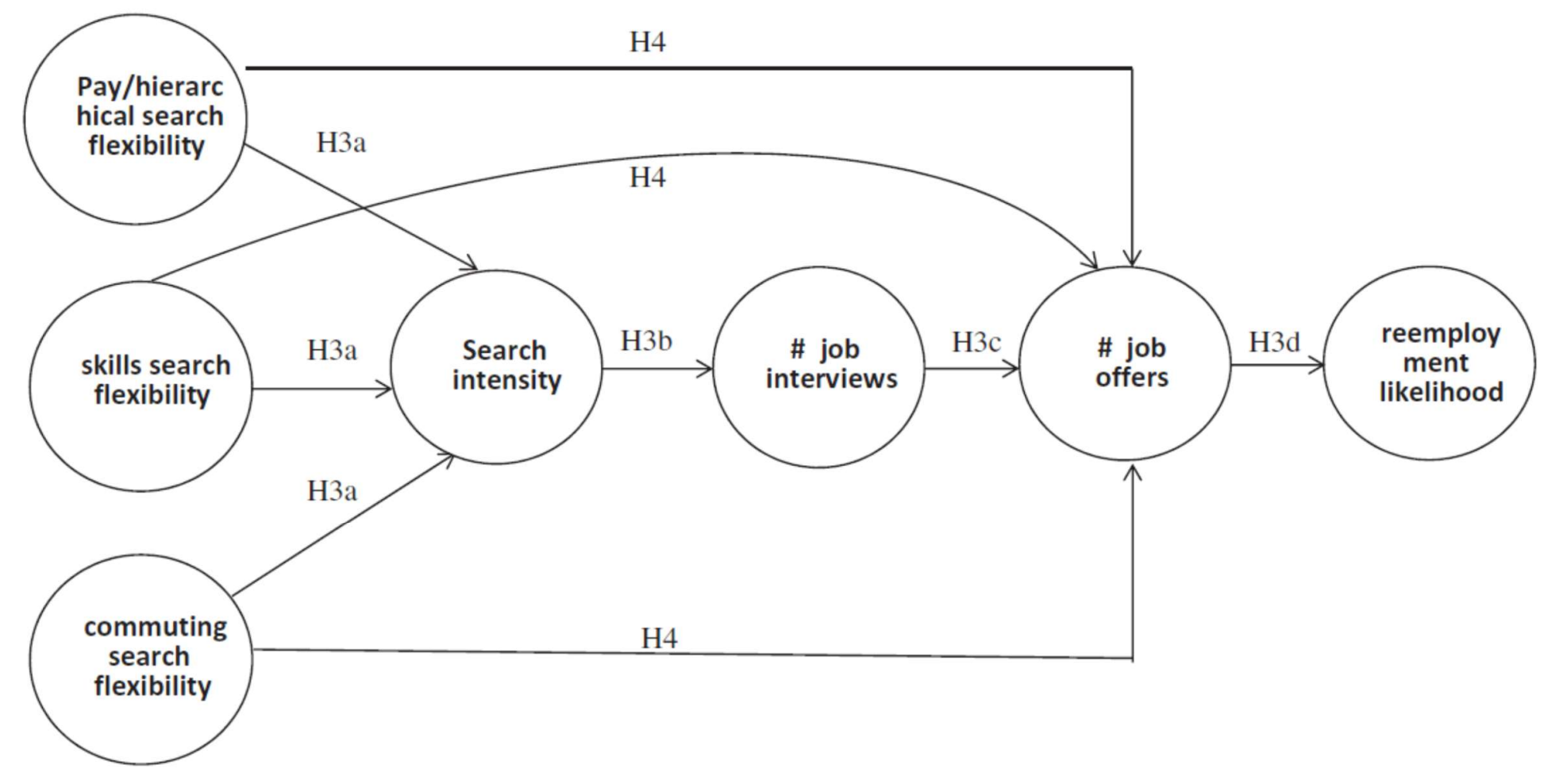


Figure 2. Results of the SEM-model $(N=672)$.

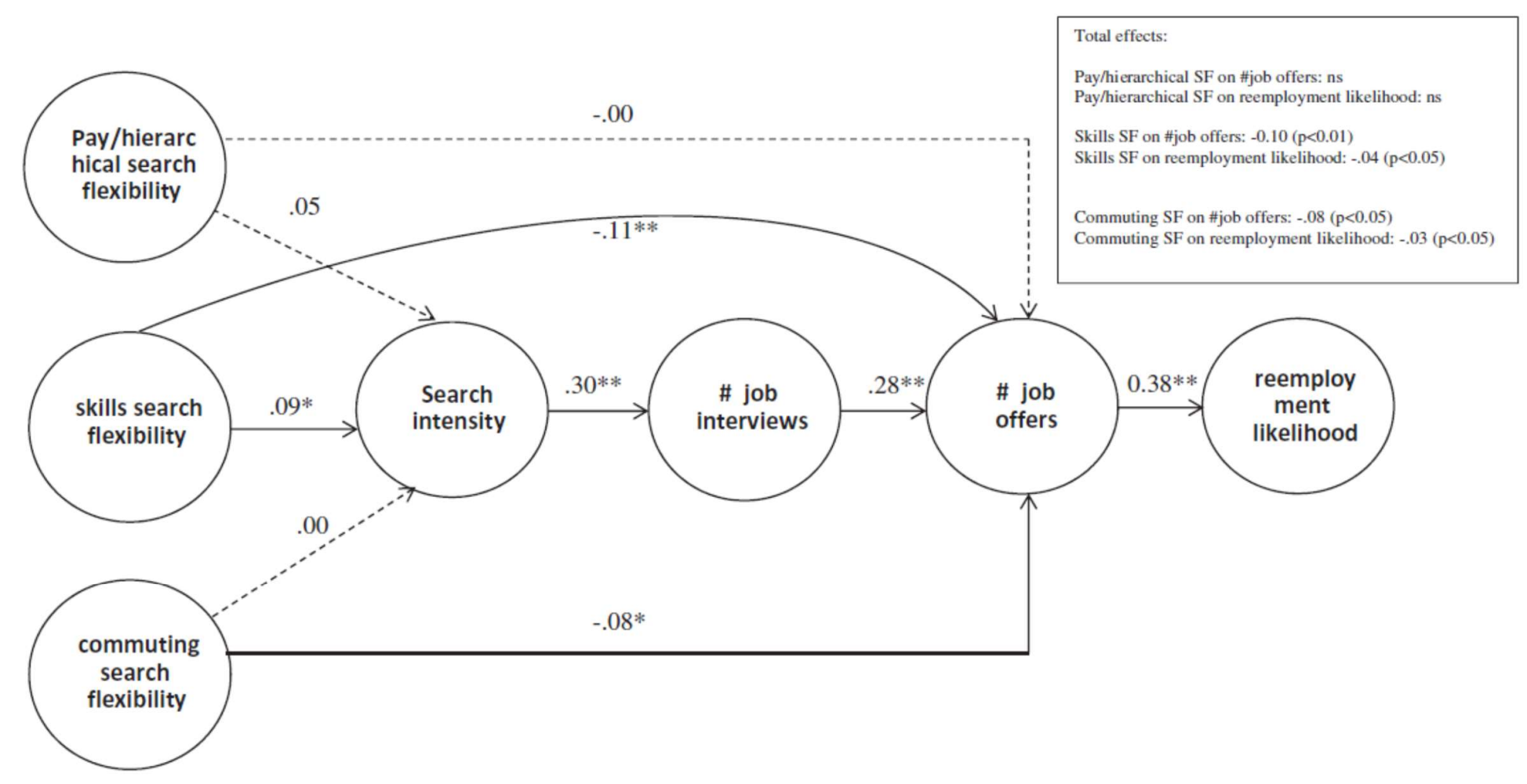

Note: ${ }^{*} p<.01 ; * p<.05$ 
Figure 3. Standardized path coefficients of the relationship between flexible job search behavior, underemployment, and job quality ( $N=232$ ).

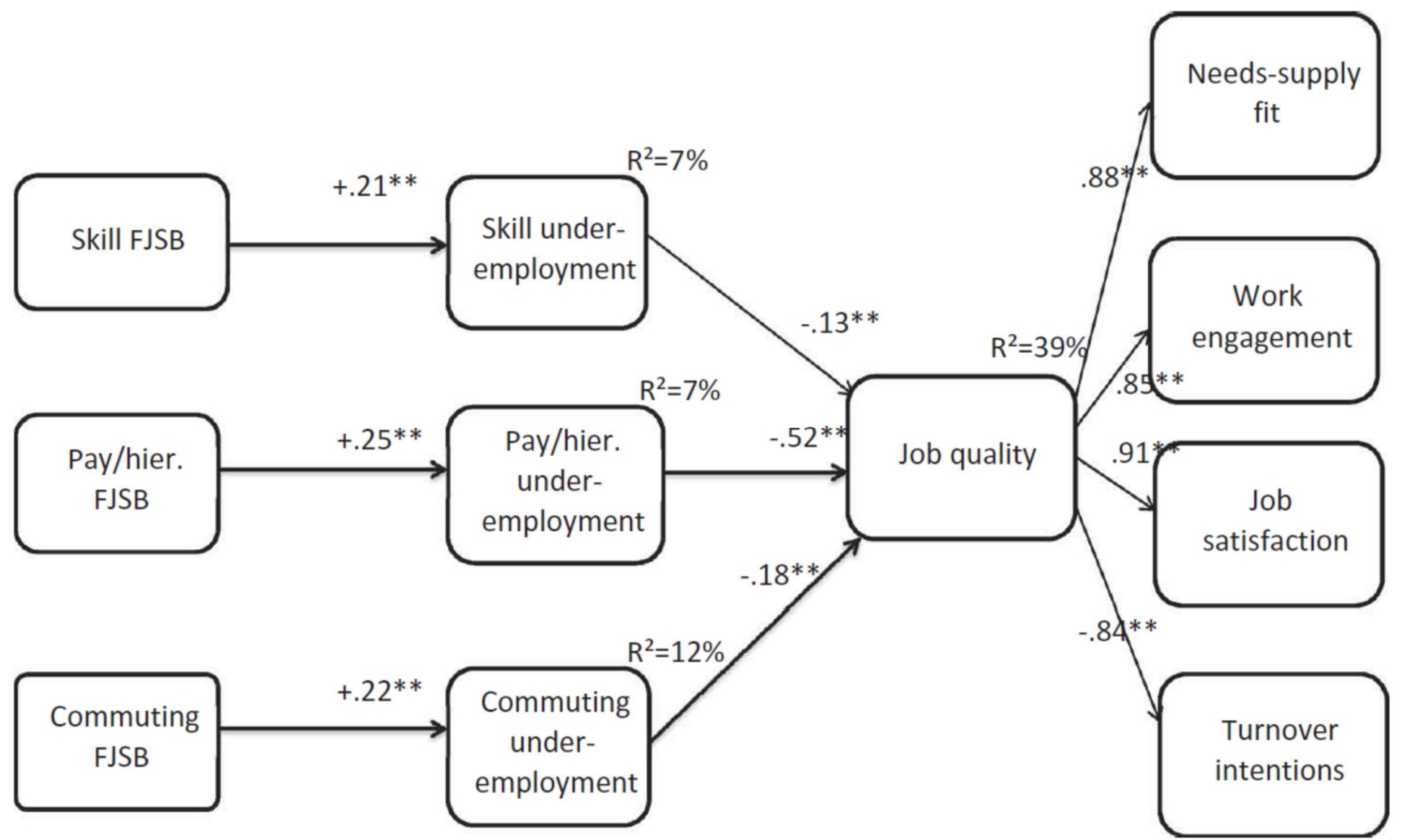

Note: $* * p<.01 ; *<.05$ 
Table 1. CFA on flexible job search dimensions (at T2)

\begin{tabular}{|c|c|c|c|c|c|}
\hline & $\chi^{2}(d f)$ & SRMR & RMSEA & $\mathrm{CFI}$ & $\chi^{2}$-difference test \\
\hline M3: three factor model & $348.70(24)$ & 0.06 & 0.11 & 0.91 & $\begin{array}{l}\text { M3 vs M2a: } \Delta \chi^{2}(2)=51.08 ; p<.01 \\
\text { M3 vs } M 2 b: \Delta \chi^{2}(2)=11.29 ; \\
p<.01 \\
\text { M3 vs } M 2 c: \Delta \chi^{2}(2)=944.86 ; \\
p<.01 \\
\text { M3 vs } M 1: \Delta \chi^{2}(3)=944.86 ; \\
p<.01\end{array}$ \\
\hline $\begin{array}{l}\text { M2a two factor model } \\
\qquad \quad \text { Skills and commuting flex as one } \\
\text { factor }\end{array}$ & $399.78(26)$ & 0.08 & 0.12 & 0.89 & $\begin{array}{l}\text { M2a vs M1: } \Delta \chi^{2}(1)=893.78 \\
p<.01\end{array}$ \\
\hline $\begin{array}{l}\text { M2b: two factor model } \\
\text { - } \mathrm{p} / \mathrm{h} \text { and commuting flex as one } \\
\text { factor }\end{array}$ & $359.99(26)$ & 0.06 & 0.11 & 0.90 & $\begin{array}{l}\text { M2b vs } M 1: \Delta \chi^{2}(1)=933.57 \\
p<.01\end{array}$ \\
\hline $\begin{array}{l}\text { M2c: two factor model } \\
\qquad \quad \text { Skills and } \mathrm{p} / \mathrm{h} \text { flex as one factor }\end{array}$ & $1293.56(26)$ & 0.14 & 0.21 & 0.63 & M2c vs M1: $\Delta \chi^{2}(1)=0 ; p>.05$ \\
\hline M1: one factor model & $1293.56(27)$ & 0.14 & 0.21 & 0.63 & \\
\hline
\end{tabular}

Table 2. Correlations between FJSB, search intensity and job search strategies.

\begin{tabular}{l|cccccc} 
& 1 & 2 & 3 & 4 & 5 & 6 \\
\hline 1. skills search flexibility & & & & & & \\
2. pay/hierarchical search flexibility & $.27^{* *}$ & & & & & \\
3. commuting search flexibility & $.19^{* *}$ & $.30^{* *}$ & & & & \\
4. job search intensity & $.12^{* *}$ & $.09^{* *}$ & $.11^{* *}$ & & & \\
5. haphazard job search strategy & $.13^{* *}$ & $.10^{* *}$ & .02 & $-.20^{* *}$ & & \\
6. focused job search strategy & $-.24^{* *}$ & $-.13^{* *}$ & $-.12^{* *}$ & $-.12^{* *}$ & -.05 & \\
7. explorative job search strategy & $.14^{* *}$ & .04 & $.13^{* *}$ & $.47^{* *}$ & -.04 & $-.19^{* *}$
\end{tabular}


Table 3. Means, Standard Deviations, and Correlations between FJSB and predictors.

\begin{tabular}{|c|c|c|c|c|c|c|c|c|c|c|c|c|c|}
\hline & Mean (sd) & 1 & 2 & 3 & 4 & 5 & 6 & 7 & 8 & 9 & 10 & 11 & 12 \\
\hline $\begin{array}{l}\text { 1. pay/hierarchical } \\
\text { search flexibility }\end{array}$ & $2.31(.82)$ & & & & & & & & & & & & \\
\hline $\begin{array}{l}\text { 2. skills search } \\
\text { flexibility }\end{array}$ & $3.08(1.05)$ & $.27 * *$ & & & & & & & & & & & \\
\hline $\begin{array}{l}\text { 3. commuting } \\
\text { search flexibility }\end{array}$ & $2.27(1.11)$ & $.30 * *$ & $.19 * *$ & & & & & & & & & & \\
\hline 4. financial hardship & $2.95(1.05)$ & -.02 & $.08^{* *}$ & -.03 & & & & & & & & & \\
\hline 5. subjective norms & $2.85(.84)$ & .02 & .04 & $.13^{* *}$ & $.12 * *$ & & & & & & & & \\
\hline 6. ns fit previous job & $3.40(1.15)$ & $.06 *$ & $-.21 * *$ & -.03 & -.05 & -.04 & & & & & & & \\
\hline $\begin{array}{l}\text { 7. wage previous } \\
\text { job }\end{array}$ & $\begin{array}{l}1146.52 \\
(544.56)\end{array}$ & $.10^{* *}$ & $-.08 * *$ & .05 & $-.18 * *$ & .04 & $.12 * *$ & & & & & & \\
\hline $\begin{array}{l}\text { 8. commuting time } \\
\text { previous job }\end{array}$ & $\begin{array}{l}52.10 \\
(45.53)\end{array}$ & $.09 * *$ & $-.06 *$ & $-.21 * *$ & .01 & .04 & .02 & $.12 * *$ & & & & & \\
\hline $\begin{array}{l}\text { 9. reemployment } \\
\text { efficacy }\end{array}$ & $2.33(.72)$ & $-.11 * *$ & $-.11 * *$ & .01 & $-.20 * *$ & -.02 & $.10^{* *}$ & .05 & -.03 & & & & \\
\hline 10. career resilience & $3.54(.65)$ & .04 & $.12^{* *}$ & $.14 * *$ & .02 & $.07 *$ & .05 & $.09 * *$ & $.07 *$ & $.06 *$ & & & \\
\hline 11. career planning & $3.32(.80)$ & $-.17^{* *}$ & $-.13^{* *}$ & -.03 & -.02 & .03 & .05 & .06 & .04 & $.25 * *$ & $.22 * *$ & & \\
\hline $\begin{array}{l}\text { 12. career self- } \\
\text { directedness }\end{array}$ & $3.46(.64)$ & $-.13 * *$ & -.04 & -.02 & $-.09 * *$ & .04 & $.06^{*}$ & $.11^{* *}$ & .00 & $.25 * *$ & $.30 * *$ & $.38^{* *}$ & \\
\hline $\begin{array}{l}\text { 13. job search self- } \\
\text { efficacy }\end{array}$ & $2.95(.33)$ & $.06 *$ & -.02 & .05 & $.06 *$ & $.12 * *$ & .01 & .04 & .04 & $.09 * *$ & $.16^{* *}$ & $.16^{* *}$ & $.18^{* *}$ \\
\hline
\end{tabular}

Note: $* * p<.01 ; * p<.05$

Table 4. Means, Standard Deviations, and Correlations between FJSB, job search intensity and search success $(n=672)$.

\begin{tabular}{|c|c|c|c|c|c|c|c|}
\hline & Mean (sd) & 1 & 2 & 3 & 4 & 5 & 6 \\
\hline $\begin{array}{l}\text { 1. pay/hierarchical search } \\
\text { flexibility }\end{array}$ & $2.31(.82)$ & & & & & & \\
\hline 2. skills search flexibility & $3.07(1.02)$ & $.27 * *$ & & & & & \\
\hline $\begin{array}{l}\text { 3. commuting search } \\
\text { flexibility }\end{array}$ & $2.31(1.10)$ & $.26^{* *}$ & $.19 * *$ & & & & \\
\hline 4. search intensity & $3.37(.73)$ & $.11 * *$ & $.15 * *$ & $.10^{*}$ & & & \\
\hline 5. jobinterviews & $2.93(4.18)$ & .04 & .06 & $.10 * *$ & $.29 * *$ & & \\
\hline 6. job offers & $1.01(1.59)$ & $-.08 *$ & $-.10 *$ & -.06 & .05 & $.28 * *$ & \\
\hline $\begin{array}{l}\text { 7. reemployment } \\
\text { likelihood }\end{array}$ & $.35(.48)$ & -.06 & .00 & .03 & .06 & $.19 * *$ & $.40 * *$ \\
\hline
\end{tabular}


Table 5. Means, Standard Deviations, and Correlations between FJSB and reemployment quality indicators $(\mathbf{n}=232)$.

\begin{tabular}{|c|c|c|c|c|c|c|c|c|c|c|}
\hline & Mean (sd) & 1 & 2 & 3 & 4 & 5 & 6 & 7 & 8 & 9 \\
\hline $\begin{array}{l}\text { 1. pay/hierarchical search } \\
\text { flexibility }\end{array}$ & $2.25(.84)$ & & & & & & & & & \\
\hline 2. skills search flexibility & $3.12(1.00)$ & $.33 * *$ & & & & & & & & \\
\hline $\begin{array}{l}\text { 3. commuting search } \\
\text { flexibility }\end{array}$ & $2.37(1.13)$ & $.26^{* *}$ & $.21 * *$ & & & & & & & \\
\hline $\begin{array}{l}\text { 4. pay /hierarchical } \\
\text { underemployment }\end{array}$ & $2.32(1.09)$ & $.23 * *$ & .06 & .01 & & & & & & \\
\hline 5. skill underutilization & $2.74(1.17)$ & -.00 & $.23^{* *}$ & .02 & $.26^{* *}$ & & & & & \\
\hline $\begin{array}{l}\text { 6. commuting time } \\
\text { underemployment }\end{array}$ & $2.44(1.54)$ & .05 & .10 & $.26^{* *}$ & -.02 & .01 & & & & \\
\hline 7. needs-supply fit & $3.40(1.02)$ & -.11 & $-.15^{*}$ & -.03 & $-.57 * *$ & $-.32 * *$ & $-.16^{*}$ & & & \\
\hline 8. work engagement & $3.81(.83)$ & $-.18 * *$ & $-.16^{*}$ & $-.15^{*}$ & $-.43 * *$ & $-.22 * *$ & -.12 & $.76^{* *}$ & & \\
\hline 9. job satisfaction & $5.30(1.34)$ & -.06 & -.03 & -.10 & $-.47 * *$ & $-.20 * *$ & $-.18^{*}$ & $.79 * *$ & $.76^{* *}$ & \\
\hline 10. turnover intentions & $1.96(1.22)$ & .11 & .07 & $.19 * *$ & $.47^{* *}$ & $.20 * *$ & $.21 * *$ & $-.70 * *$ & $-.70 * *$ & $-.79 * *$ \\
\hline
\end{tabular}
Note: $* * p<.01 ; * p<.05$ 
Table 6. Results of the regression analysis of the antecedents of FJSB (Standardized coefficients).

\begin{tabular}{|c|c|c|c|c|c|c|c|c|c|}
\hline & \multicolumn{3}{|c|}{$\begin{array}{c}\text { Pay/hierarchical search } \\
\text { flexibility } \\
(N=934)^{1} \\
\end{array}$} & \multicolumn{3}{|c|}{$\begin{array}{l}\text { Skills search flexibility } \\
\qquad(N=1049)^{1}\end{array}$} & \multicolumn{3}{|c|}{$\begin{array}{l}\text { Commuting search flexibility } \\
\qquad(N=984)^{1}\end{array}$} \\
\hline & Step 1 & Step 2 & Step 3 & Step 1 & Step 2 & Step 3 & Step 1 & Step 2 & Step 3 \\
\hline age & $.09 *$ & $.08^{*}$ & .04 & $-.12 * *$ & $-.13 * *$ & $-.10 * *$ & $-.09 * *$ & $-.10 *$ & -.05 \\
\hline female & $-.10 *$ & $-.10 * *$ & $-.10 * *$ & -.02 & -.02 & -.02 & $-.15 * *$ & $-.15 * *$ & $-.14 * *$ \\
\hline origin & -.03 & -.03 & -.03 & -.03 & -.03 & -.03 & -.00 & .01 & .00 \\
\hline low education & -.02 & -.03 & .00 & .00 & -.00 & -.00 & -.04 & -.05 & -.06 \\
\hline unemployment duration & $.09^{* *}$ & $.08^{*}$ & $.07 *$ & -.00 & .00 & -.02 & .05 & .05 & .05 \\
\hline career planning & & $-.13 * *$ & $-.12 * *$ & & $-.15 * *$ & $-.13 * *$ & & -.01 & .00 \\
\hline career resilience & & .06 & .06 & & $.17 * *$ & $.17 * *$ & & $.18^{* *}$ & $.18^{* *}$ \\
\hline career self-directedness & & $-.11 * *$ & $-.11 * *$ & & -.05 & -.02 & & $-.08^{*}$ & $-.08^{*}$ \\
\hline job search self-efficacy & & .05 & .05 & & -.02 & -.03 & & .02 & .03 \\
\hline wage previous job (In) & & & $.10 * *$ & & & & & & \\
\hline $\begin{array}{l}\text { needs-supply fit previous } \\
\text { job } \\
\text { commuting time previous } \\
\text { job }\end{array}$ & & & & & & $-.20 * *$ & & & $-.25 * *$ \\
\hline reemployment efficacy & & & $-.08^{*}$ & & & -.06 & & & -.03 \\
\hline financial hardship & & & -.02 & & & .05 & & & $.07 *$ \\
\hline subjective norms & & & -.03 & & & .01 & & & $10^{* *}$ \\
\hline Adjusted R ${ }^{2}$ & $.03 * *$ & $.06 * *$ & $.06 * *$ & $.01 * *$ & $.05^{* *}$ & $.10 * *$ & $.02 * *$ & $.05^{* *}$ & $.12 * *$ \\
\hline $\mathbf{R}^{2}$ & $.03 * *$ & $.06^{* *}$ & $.08 * *$ & $.02 * *$ & $.06^{* *}$ & $.11^{* *}$ & $.03 * *$ & $.06^{* *}$ & $.13 * *$ \\
\hline$\Delta \mathbf{R}^{2}$ & & $.03 * *$ & $.01 * *$ & & $.04 * *$ & $.05 * *$ & & $.03 * *$ & $.07 * *$ \\
\hline
\end{tabular}

Note: ${ }^{1}$ Respondents with incomplete records on any of the variables under study were excluded from the regression.

$* * p<.01 ; * p<.05$

Table 7. Testing for inconsistent mediation

\begin{tabular}{l|l|l|l|l|l}
\hline & $\chi^{2}$ (df) & SRMR & RMSEA & CFI & $\chi^{2}$-difference test \\
\hline M1 Full mediation model & $26.28(23)$ & 0.02 & 0.02 & 1.00 & $\begin{array}{l}\text { M1 vs M2: } \Delta \chi^{2}(3)=15.04 ; p<.01 \\
\text { M1 vs M3: } \Delta \chi^{2}(3)=11.05 ; p<.05 \\
\text { M1 vs M4: } \Delta \chi^{2}(1)=52.14 ; p<.01\end{array}$ \\
\hline M2 Model without direct effect & $41.32(26)$ & 0.02 & 0.03 & 0.98 & \\
\hline $\begin{array}{l}\text { M3 Model without effect from causal } \\
\text { variable to mediator }\end{array}$ & $37.33(26)$ & 0.02 & 0.03 & 0.99 & \\
\hline $\begin{array}{l}\text { M4 model without effect from mediator to } \\
\text { outcome }\end{array}$ & $78.42(24)$ & 0.03 & 0.06 & 0.94 & \\
\hline
\end{tabular}

